NBSIR 84-2916

\title{
Evaluation of Infrared Reflectance as a Technique for Measuring Absorber Materials Degradation
}

David Waksman

Willard E. Roberts

U.S. DEPARTMENT OF COMMERCE

National Bureau of Standards

Center for Building Technology

Gaithersburg, MD 20899

September 1984

Prepared for:

Active Heating and Cooling Division Jffice of Solar Heat Technologies

QC J.S. Department of Energy Nashington, DC 20585 

EVALUATION OF INFRARED REFLECTANCE AS A TECHNIQUE FOR MEASURING ABSORBER MATERIALS DEGRADATION

David Waksman

Willard E. Roberts

U.S. DEPARTMENT OF COMMERCE

National Bureau of Standards

Center for Building Technology

Gaithersburg, MD 20899

September 1984

Prepared for:

Active Heating and Cooling Division

Office of Solar Heat Technologies

U.S. Department of Energy

Washington, DC 20585

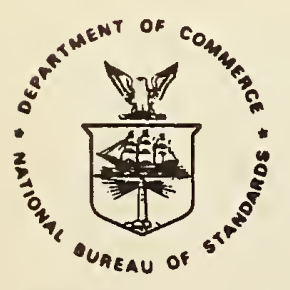

U.S. DEPARTMENT OF COMMERCE, Malcolm Baldrige, Secretary NATIONAL BUREAU OF STANDARDS, Ernest Ambler, Director 

LIST OF TABLES $\ldots \ldots \ldots \ldots \ldots \ldots \ldots \ldots \ldots \ldots \ldots \ldots \ldots \ldots \ldots \ldots \ldots \ldots$

LIST OF FIGURES $\ldots \ldots \ldots \ldots \ldots \ldots \ldots \ldots \ldots \ldots \ldots \ldots \ldots \ldots \ldots \ldots \ldots \ldots \ldots \quad v$

ABSTRACT $\ldots \ldots \ldots \ldots \ldots \ldots \ldots \ldots \ldots \ldots \ldots \ldots \ldots \ldots \ldots \ldots \ldots \ldots \ldots \ldots \ldots$

1. INTRODUCTION $\ldots \ldots \ldots \ldots \ldots \ldots \ldots \ldots \ldots \ldots \ldots \ldots \ldots \ldots \ldots \ldots \ldots \ldots$

2. EXPERIMENTAL $\ldots \ldots \ldots \ldots \ldots \ldots \ldots \ldots \ldots \ldots \ldots \ldots \ldots \ldots \ldots \ldots \ldots \ldots$

2.1 Property Measurements .......................... 2

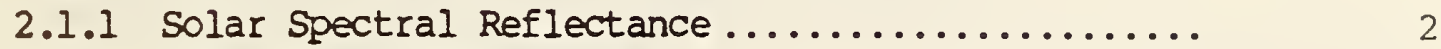

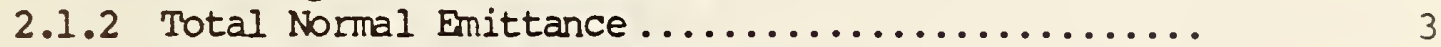

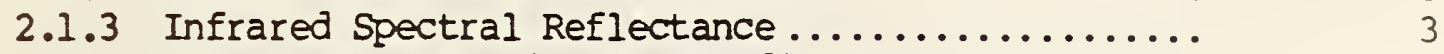

2.1.4 Surface Characterization Studies ................ 4

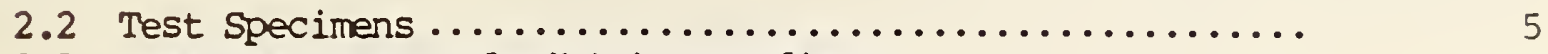

2.3 Measurement Reproducibility Studies................. 5

3. RESULTS AND DISCUSSION .......................... 6

3.1 Reproducibility Studies $\ldots \ldots \ldots \ldots \ldots \ldots \ldots \ldots \ldots \ldots \ldots \ldots$

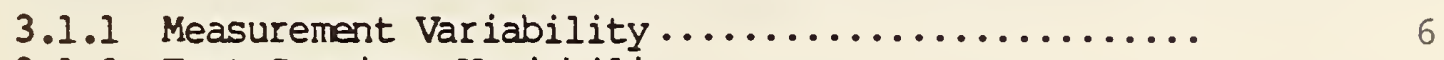

3.1 .2 Test Specimen Variability .................. 7

3.2 Optical Measurement of Materials Property Changes....... 8

4. CONCLUSIONS AND RECOMMENDATIONS ..................... 9

5. ACKNOWLEDGEMENTS ............................ 10

6. REFERENCES $\ldots \ldots \ldots \ldots \ldots \ldots \ldots \ldots \ldots \ldots \ldots \ldots \ldots \ldots \ldots \ldots \ldots \ldots . \ldots \ldots \ldots$ 


\section{LIST OF TABLES}

$\underline{\text { Page }}$

Table 1. Series 1 Absorber Test Specimens ................ 12

Table 2. Series 2 Absorber Test Specimens ................ 13 


\section{LIST OF FIGURES}

Figure 1. The measurement spectrum of the Gier Dunkle Infrared

Reflectometer, Model DB-100, (no filters) together with a normalized $100^{\circ} \mathrm{C}$ blackbody spectrum as presented by Pettit, reference [7]

Figure 2. Reproducibility spectrum for 45 degree specular IR reflectance,

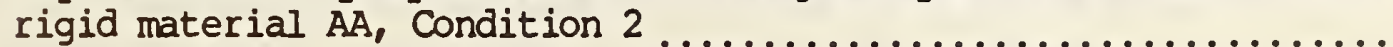

Figure 3. Reproducibility spectra for 45 degree specular infrared reflectance, foil material AM, Condition 2

Figure 4. Variability in 45 degree specular infrared reflectance spectra for several unaged samples of rigid material AA

Figure 5. Variability in combined diffuse and specular infrared reflectance spectra for several unaged samples of rigid material AA......... 18

Figure 6. Variability in 45 degree specular infrared reflectance for several unaged samples of rigid material AJ

Figure 7. Variability in combined diffuse and specular infrared reflectance spectra for several unaged samples of rigid material $\mathrm{AJ} . . . . . \ldots \ldots$.

Figure 8. Variabililty in 45 degree specular infrared reflectance for several unaged samples of rigid material AP

Figure 9. Variability in combined diffuse and specular infrared reflectance spectra for several unaged samples of rigid material AP ..........

Figure 10. Variability in 45 degree specular infrared reflectance for several

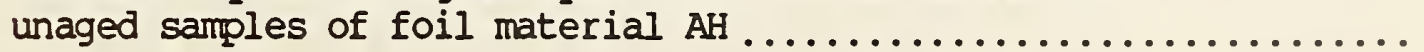

Figure 11. Variability in combined diffuse and specular infrared reflectance spectra for several unaged samples of foil material AH .......... 24

Figure 12. Variability in 45 degree specular infrared reflectance for several unaged samples of foil material $\mathrm{AW}$.

Figure 13. Variability in combined diffuse and specular infrared reflectance spectra for several unaged samples of foil material $A W: \ldots \ldots \ldots \ldots$

Figure 14. Comparison of changes in emittance with combined diffuse and specular infrared reflectance spectra for aged and unaged samples of material $A A$

Figure 15. Comparison of changes in emittance with 20 degree infrared reflectance spectra for aged and unaged samples of material AA...

Figure 16. Comparison of changes in emittance with 45 degree infrared reflectance spectra for aged and unaged samples of material AA... 
Figure 17. Comparison of changes in emittance with 75 degree infrared reflectance spectra for aged and unaged samples of material AA... 30

Figure 18. Comparison of changes in emittance with combined diffuse and specular infrared reflectance spectra for aged and unaged samples

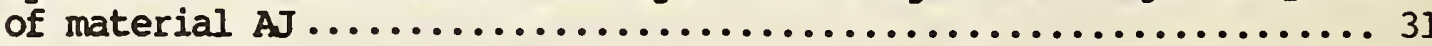

Figure 19. Comparison of changes in emittance with 20 degree infrared reflectance spectra for aged and unaged samples of material AJ... 32

Figure 20. Comparison of changes in emittance with 45 degree infrared reflectance spectra for aged and unaged samples of material AJ... 33

Figure 21. Comparison of changes in emittance with 75 degree infrared reflectance spectra for aged and unaged samples of material AJ... 34

Figure 22. Comparison of changes in emittance with combined diffuse and specular infrared reflectance spectra for aged and unaged samples of material AP........................................ 35

Figure 23. Comparison of changes in emittance with 20 degree infrared reflectance spectra for aged and unaged samples of material AP.... 36

Figure 24. Comparison of changes in emittance with 45 degree infrared reflectance spectra for aged and unaged samples of material AP.... 37

Figure 25. Comparison of changes in emittance with 75 degree infrared reflectance spectra for aged and unaged samples of material AP.... 38 
EVALUATION OF INFRARED REFLECTANCE AS A TECHNIQUE FOR MEASURING ABSORBER MATERIALS DEGRADATION

David Waksman and Willard E. Roberts

\section{ABSTRACT}

Current ASTM standards concerned with the durability and reliability of absorptive materials rely on integrated solar absorptance and emittance as the primary methods for assessing changes in absorber optical performance resulting from environmental exposure. This study was undertaken to determine if infrared reflectance measurements are a more sensitive technique for detecting absorber materials degradation. Spectral measurements were made to identify factors that could affect the reproducibility of infrared reflectance measurements and to compare their ability to detect changes with currently used methods for absorber materials. Recommendations are made concerning the use and limitations of infrared reflectance measurements for this purpose. 

At the present time, integrated solar absorptance per ASTM E 424 (1)* and emittance per ASTM E 408 (2) are the primary techniques used by the solar industry to measure changes in the optical performance of absorptive materials. These methods have been incorporated into ASTM procedures concemed s with the evaluation of absorptive materials used in solar collectors $(3,4)$.

Studies conducted at NBS (5) have shown that integrated solar absorptance measurements are a relatively insensitive indicator of absorber materials degradation. Changes that occur in a limited portion of the solar spectrum, i.e., in the near infrared where there is a small amount of energy, are often concealed by the integration process conducted as part of ASTM E 424. ASTM E 408 measurements are a more sensitive indicator of changes in the performance of many selective absorber materials; however, this technique provides no information about the spectral distribution of changes in the optical performance of these materials.

Preliminary measurements made by the authors indicated that infrared spectral reflectance measurements offer promise as a technique for the early detection of absorber materials degradation. This study was conducted to determine whether or not these measurements are more sensitive indicators of changes in the optical properties of absorber materials than current practice. Measurement techniques evaluated included diffuse and specular infrared reflectance, infrared emittance, and integrated solar absorptance.

* Numbers in parentheses indicate references given at the end of this report. 


\section{EXPERIMENIAL}

\subsection{PROPERTY MEASUREMENTS}

The property measurements used in this study are described in the following sections. An alignment fixture was used in each instrument to ensure that approximately the same sample area was measured each time a measurement was made on the same sample.

\subsubsection{Solar Spectral Reflectance}

Spectral reflectance and solar absorptance were determined in accordance with ASTM E 424, method A (1) using a spectrophotometer equipped with a 76 mm integrating sphere coated with barium sulfate paint. Spectral reflectance measurements were made over the wavelength range from 300 to $2150 \mathrm{~nm}$ using a lead sulfide detector above $700 \mathrm{~nm}$ and a photamultiplier detector below this wavelength. The incident monochromatic radiation was 7 degrees off the normal to the plane of the specimen and the reflected radiation was measured using an integrating sphere. A pressed polytetrafluoroethylene powder (Halon) reference standard was used for the reflectance measurements. Solar energy absorptance was calculated using the distribution of solar energy reported by Parry Moon for sea level and air mass 2 (6). The weighted ordinates calculation method described in ASTM E 424 was used to integrate the energy distribution at $50 \mathrm{~nm}$ intervals. The spectral reflectance data were digitized by the spectrophotometer and fed directly into a computer which performed the integration calculations after correcting for the baseline values abtained with the Halon reference standard. 


\subsubsection{Total Normal Emittance}

Total normal emittance was measured in accordance with ASTM E 408, method A (2). The infrared reflectometer used incorporates a rotating cavity mounted below a $20 \mathrm{~mm}$ diameter sample measurement port. The inside of the cavity is divided into two semicylindrical chambers, both coated black. One chamber is heated to approximately $45^{\circ} \mathrm{C}$; the other is unheated but reaches approximately $33^{\circ} \mathrm{C}$. As the cavity rotates, a sample placed over the measurement port is alternately irradiated with black body radiation corresponding to the temperature of each chamber. The detector system is positioned so that it views the sample in a near normal direction. The sample reflectance is averaged over a spectral distribution which is given by the difference between black body spectral irradiance curves at the two chamber temperatures. As shown by Pettit (7), this distribution, when normalized, very closely approximates the $100^{\circ} \mathrm{C}$ black body spectrum, see figure 1 , and has maximum relative intensity at approximately $7.7 \mathrm{M} \mathrm{m}$ when the instrument is used without a polyethylene filter in the optical path between the sample and the detector. The instrument, as normally manufactured, includes this filter which was not used in this study. The purpose of the polyethylene filter is to shift the approximately $100^{\circ} \mathrm{C}$ black body spectrum to one of approximately $25^{\circ} \mathrm{C}$. Gold $(\epsilon=0.045)$ and black $(\epsilon=0.911$ ) reference standards were used for calibration purposes. The instrument is capable of reproducing emittance $(\epsilon)$ values to within 0.002 using these reference standards.

\subsubsection{Infrared Spectral Reflectance}

Diffuse and specular infrared reflectance of absorber materials were measured using a fourier transform infrared (FT-IR) spectrometer. The instrument 
incorporates a large removable sample chamber onto which various types of attachments are fitted. The chamber rides on a track, and alignment pins and stops are provided for precision al ignment. Combined diffuse and specular measurements were made using a Harrick Diffuse Reflectance Attachment*. The design uses two 90 degree off-axis ellipsoids which subtend 20 percent of the $4 \pi$ solid angle. The samples were tilted forward at an angle of 30.75 degrees to include both the specular and diffuse reflectance components of the radiation. Specular measurements were made using a Barnes* variable angle specular reflectance attachment. Specular measurements were made at angles of 20, 45 and 75 degrees off the normal to the plane of the test specimen to determine if the reflectance measurements are angular dependent. A silver front surface mirror was used to obtain a background reference spectrum every time a setting on the instrument was changed, or a mirror, or an attachment was moved.

\subsubsection{Surface Characterization Studies}

Optical and scanning electron microscope studies were conducted on several samples to determine if there was a correlation between surface characteristics and infrared reflectance measurements. Optical observations were made using a low power light microscope. Scanning electron microscope studies were conducted at magnifications of 200 and 600 times.

* Product names are included, where necessary, for informational purposes only. Their use does not constitute an endorsement by the National Bureau of Standards. 


\subsection{TEST SPECIMENS}

Two series of test specimens were used in this study. The first series consisted of absorber material samples subjected to various types of indoor laboratory environmental exposure tests in a previous study conducted at NBS (5). These samples were selected for use in this study because of the broad range of appearance and optical property changes induced in samples of the same composition by various types of environmental exposures. They thus provided a basis for evaluating the ability of the optical measurement techniques studied to detect changes caused by absorber materials degradation. The series 1 specimens, the aging conditions used and their solar absorptance and emittance are listed in table 1. All of the absorber coatings were applied on rigid, relatively flat, metal substrates; this is a consideration that will become important in later discussions.

The series 2 test specimens consisted of the five types of selective absorber materials applied on metal foils listed in table 2. The foil samples had a considerable amount of wrinkling. Samples of these materials were mechanically attached to rigid aluminum backing plates. Optical property measurements were made on unaged replicate samples of these materials to assess the influence of this foil wrinkling on measurement reproducibility.

\subsection{MEASUREMENT REPRODUCIBILITY STUDIES}

Studies were conducted to determine the influence of sample and reflectance attachment placement on the reproducibility of diffuse and specular infrared reflectance measurements. All parameters within the FT-IR spectrometer were 
maintained the same, i.e. gain, iris diameter, number of scans, etc. The only changes made were to the specimen, specimen fixture, reflectance attachments, and chamber. For each condition evaluated, ten runs were made and compared. The conditions were as follows:

1. Specimen, specimen fixture, reflectance attachment, and chamber all fixed in position, with ten runs made without touching any part of the system.

2. Specimen taken out and replaced between runs; specimen fixture, reflectance attachment and chamber fixed.

3. Specimen and specimen fixture taken out and replaced; reflectance attachment and chamber fixed.

4. Reflectance attachment and specimen removed and then replaced; chamber fixed.

5. Chamber removed and replaced; reflectance attachment, specimen fixture and specimen fixed in place inside chamber.

3. RESUITS AND DISCUSSION

\subsection{REPRODUCIBIIITY STUDIES}

\subsubsection{Measurement Variability}

Infrared reflectance measurement reproducibility studies were conducted primarily using the specular reflectance attachment set at an angle of 45 degrees. The multiple curves obtained overlapped one another for the conditions in wich all of the sample measurement parameters were kept fixed and in which just the sample chamber was moved in and out conditions one and 
five, respectively). Condition two, in which the specimen was taken out and replaced between runs, with all of the other parameters remaining fixed, produced overlapping curves for an AA specimen, which had a rigid metal substrate, and an approximately three percent spread in the curves for the thin foil samples of material AM which had a wrinkled surface (figures 2 and 3, respectively). Moving the test specimen and alignment fixture, with the specular reflectance attachment and chamber fixed (condition three) also produced a family of curves that overlapped one another for an AA ( $r$ igid) specimen. With the diffuse attachment, there was a one to two percent spread for foil material AM and slightly less for material AA using the condition three parameters. Condition four, where the specimen, fixture and specular attachment were moved and the chamber remained fixed, also produced a one to two percent spread for material AM and slightly less for material AA.

\subsubsection{Test Specimen Variability}

Figures 4 through 9 illustrate the type of spread in spectral infrared reflectance curves that can be expected for samples of several different rigid absorber materials taken from a single larger sheet of each material. All of the samples were unaged. Factors that could influence the relatively large spread in the spectral curves include the surface roughness and uniformity of the absorber material and the size of the sample area viewed by the spectrometer. The combined diffuse and specular infrared spectral reflectance curves appear to have considerably less spread than the 45 degree specular curves. Figures 10 through 13 show that the spreads in infrared curves obtained for unaged foil specimens are somewhat greater than those obtained for absorptive materials on rigid substrates. This is most likely due to the combination of wrinkling of the foil and the small sample area measured by the 
FT-IR spectrometer. The combined specular and diffuse curves measured for the unaged foil samples also had considerably less spread than the 45 degree specular measurements. The spreads in specular curves measured with an incident angle of 75 degrees were approximately the same as those obtained at 45 degrees.

\subsection{OPTICAL MEASURENENT OF MATERIALS PROPERTY CHANGES}

Figures 14 through 25 compare emittance with the specular and combined specular and diffuse infrared reflectance curves measured on samples of three different absorber materials. These samples were subjected to the environmental exposure conditions listed in table 1 prior to the infrared reflectance measurements. All of the absorptive materials discussed in this section were applied on rigid substrates. Measurements made on absorptive materials applied on thin metal foils appeared to give inconsistent results on aging and are not reported for this reason. This may be due to wrink ling of the foils and the small sample surface area viewed by the spectrophotometer which does not average out the effects of the wrinkling.

In general, the results obtained with the rigid samples were consistent with those obtained by infrared emittance measurements, with the lower emittance specimens having higher infrared reflectance values. The large spreads obtained for some of the reflectance curves appeared to be closely related to factors such as coating flatness and smoothness, the appearance of corrosion or other degradation products on the sample surface and the extent of cracking and blistering of the coating. For absorber material AJ, there was a large spread in the reflectance curves measured for samples that had the same 
measured emittance. This appeared to be directly related to blistering of the absorber coating and, for the high emittance samples, to the formation of cracks. The reflectance curves of coatings having a similar surface appearance tended to cluster together.

Integrating the infrared spectral reflectance values with the black body energy distribution shown in figure 1 gave emittance values that were in poor agreement with those measured in accordance with ASTM E408 using an infrared reflectometer.

\section{CONCLUSIONS AND RECOMMENDATIONS}

Infrared reflectance spectra are a more sensitive indicator of changes in absorber material surface topography and composition than emittance measured in accordance with ASTM E 408, as Iisted in tables 1 and 2. However, the phenomena causing changes in the reflectance spectra are not obvious from examining the spectra.

Direct observation of changes in surface topography using optical and scanning electron microscopy, and compositional analysis where warranted, in combination with the current practice of performing absorptance and emittance measurements per ASTM E 424, method A, and ASTM E 408 appears to be a more effective use of resources, with regard to the information provided, than infrared reflectance measurements.

To minimize the influence of sample variability, optical measurements should be performed on the same test specimen before and after aging using an alignment fixture to ensure that the same sample area is viewed by the 
spectrometer. Wrinkling can cause a considerable amount of spread in the infrared reflectance spectra measured on replicate samples of absorptive coatings applied on foil substrates.

Alignment variabilities can be minimized using the FT-IR spectrometer if the reflectance attachment is kept in a fixed position in the sample chamber and used without changing its alignment until all measurements are completed. If this is not done, extreme care must be taken in attachment alignment, to ensure that the same reflected energy is going into the spectrometer when successive measurements are made.

The spectral infrared reflectance measured for materials AA, AJ and AP was considerably higher at an incident angle of 75 degrees than at 20 or 45 degrees. This is consistent with data given by Meinel and Meinel (8) which show a large decrease in emittance (increase in reflectance) at angles near grazing incidence for dielectrics.

\section{ACKNOWLEDGEMENIS}

The financial support of the Office of Solar Heat Technologies of the U.S. Department of Energy is gratefully acknowledged. The authors also thank Dr. Kent Reed of the National Bureau of Standards for his many helpful discussions. Foil backed absorber samples were abtained from Stan Moore of Los Alamos National Laboratory. 


\section{REFERENCES}

1. "Test for Solar Energy Transmittance and Reflectance (Terrestrial) of Sheet Materials," ASTM E 424-71, American Society for Testing and Materials, 1916 Race Street, Philadelphia, PA 19103.

2. "Test for Total Normal Emittance of Surfaces Using Inspection - Meter Techniques," ASTM E 408-71, ibid.

3. "Practice for Evaluating Solar Absorptive Materials for Thermal Applications," ASTM E 744-80, ibid.

4. "Practice for Evaluating Absorptive Solar Receiver Materials When Exposed to Conditions Simulating Stagnation in Solar Collectors with Cover Plates," ASIM E 781-81.

5. Waksman, D., Thomas, W.C. and Streed, E.R., "NBS Solar Collector Durability/Reliability Test Program: Final Report," NBS Technical Note 1196, National Bureau of Standards, Washington, D.C. 20234. (In publication.)

6. Smithsonian Physical Tables, Table 1, Vol. 815, 1954, p. 273 or Journal of the Franklin Institute, Vol. 230, 1940, p. 583.

7. Pettit, R.B., "Optical Measurement Techniques Applied to Solar Selective Coatings," Report No. SAND-77-0421, Sandia National Laboratories, Albuquerque, N.M. 87115, August 1977.

8. Meinel, A.B. and MeineI, M.P., Applied Solar Energy: An Introduction, Reading, Massachusetts: Addison-Wesley Publishing Company; 1976. p. 2174 . 
䔍壱|

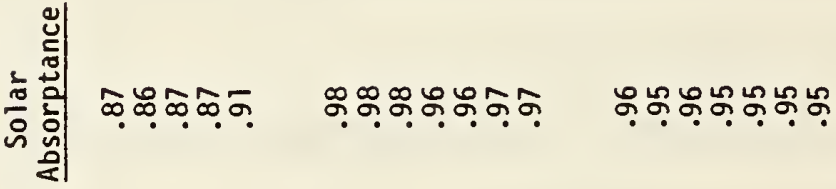

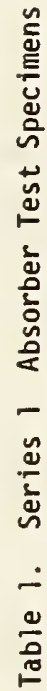

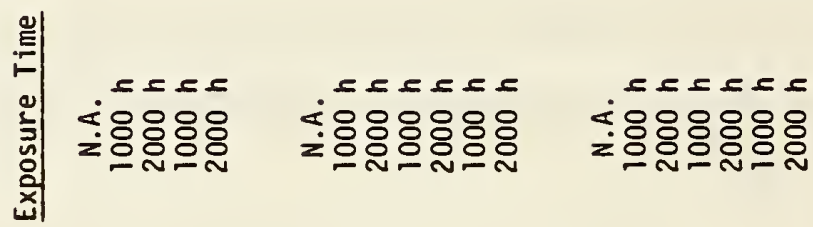

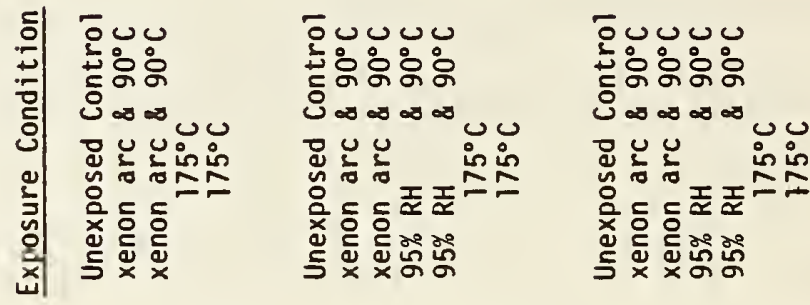

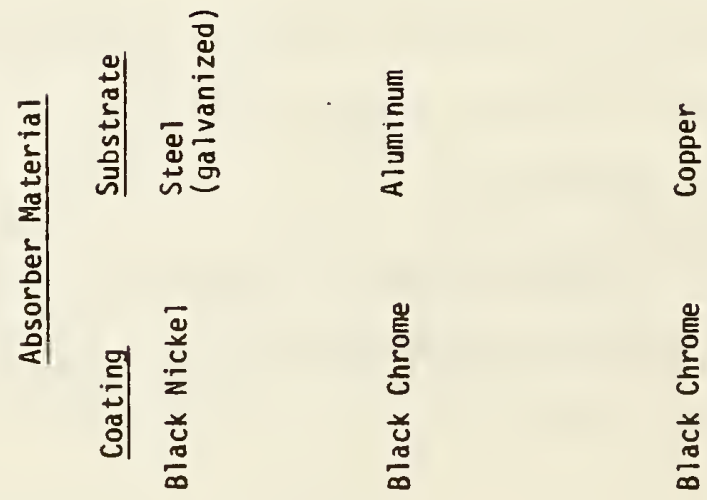

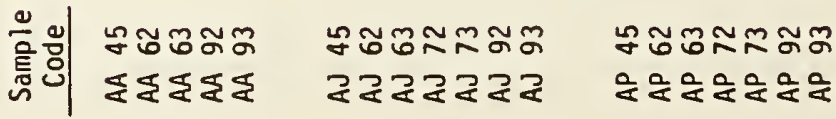




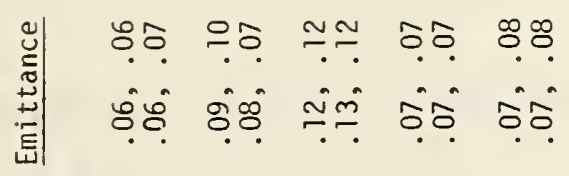

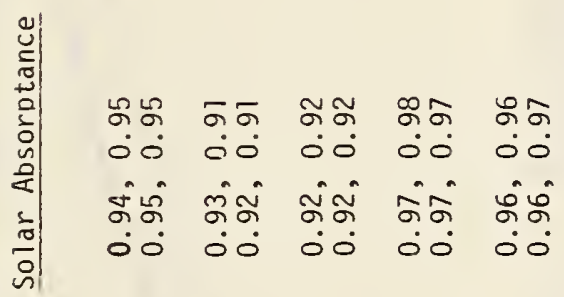
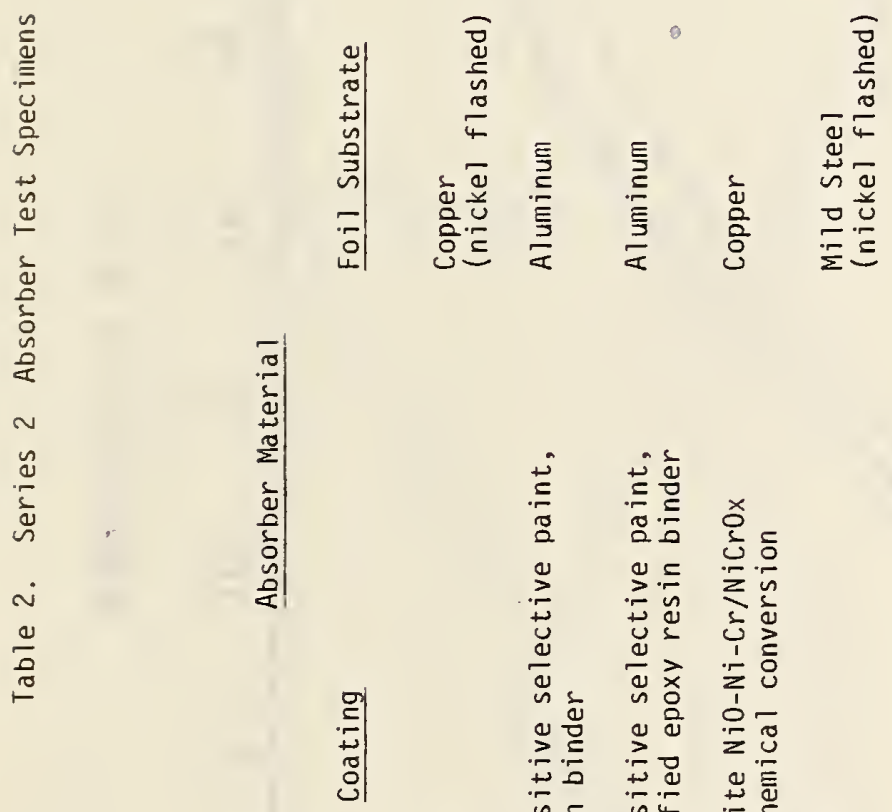

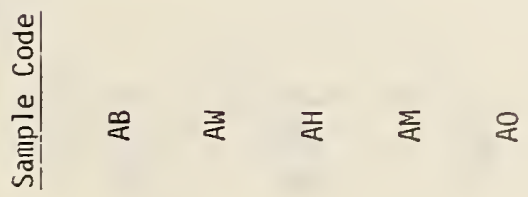




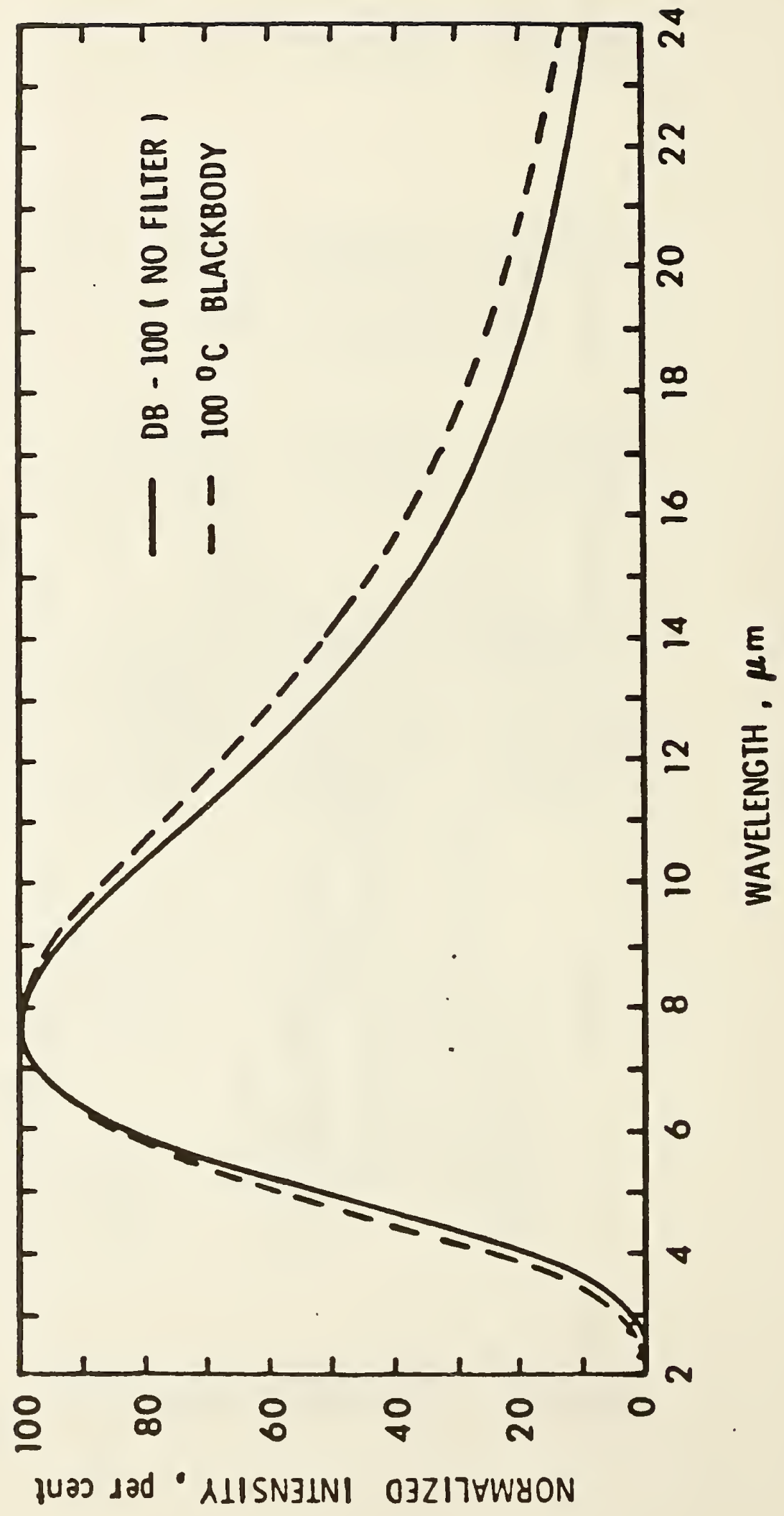

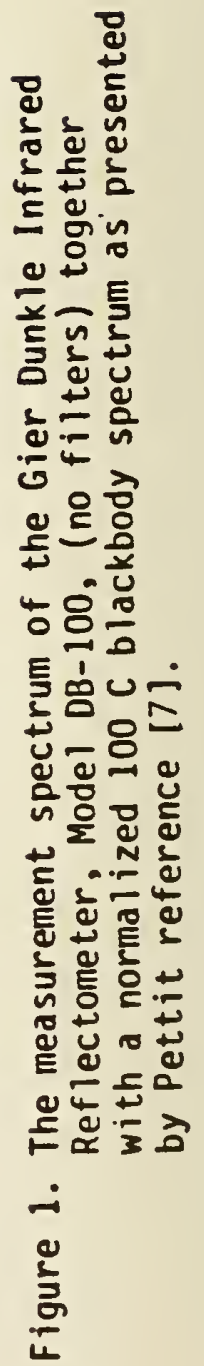




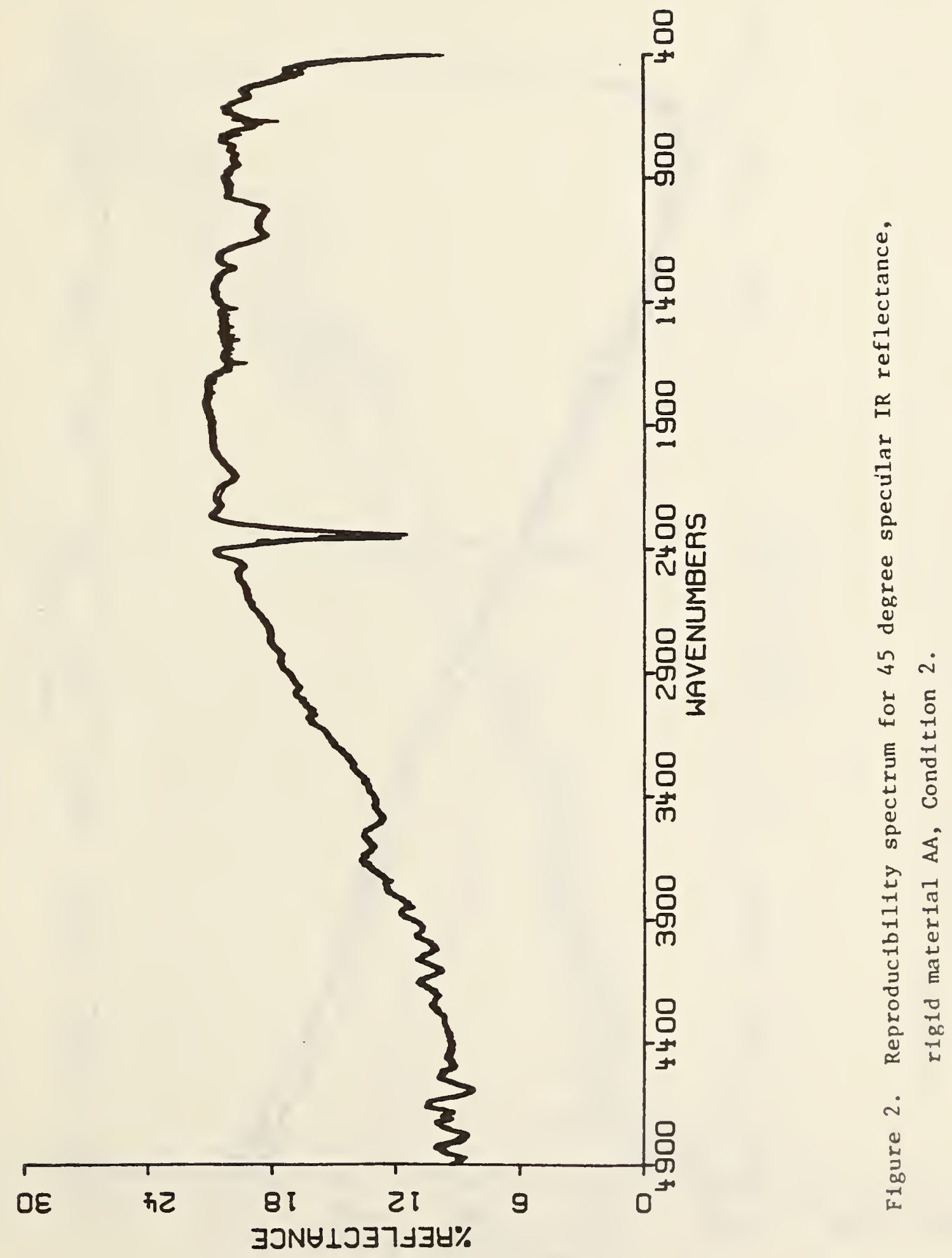




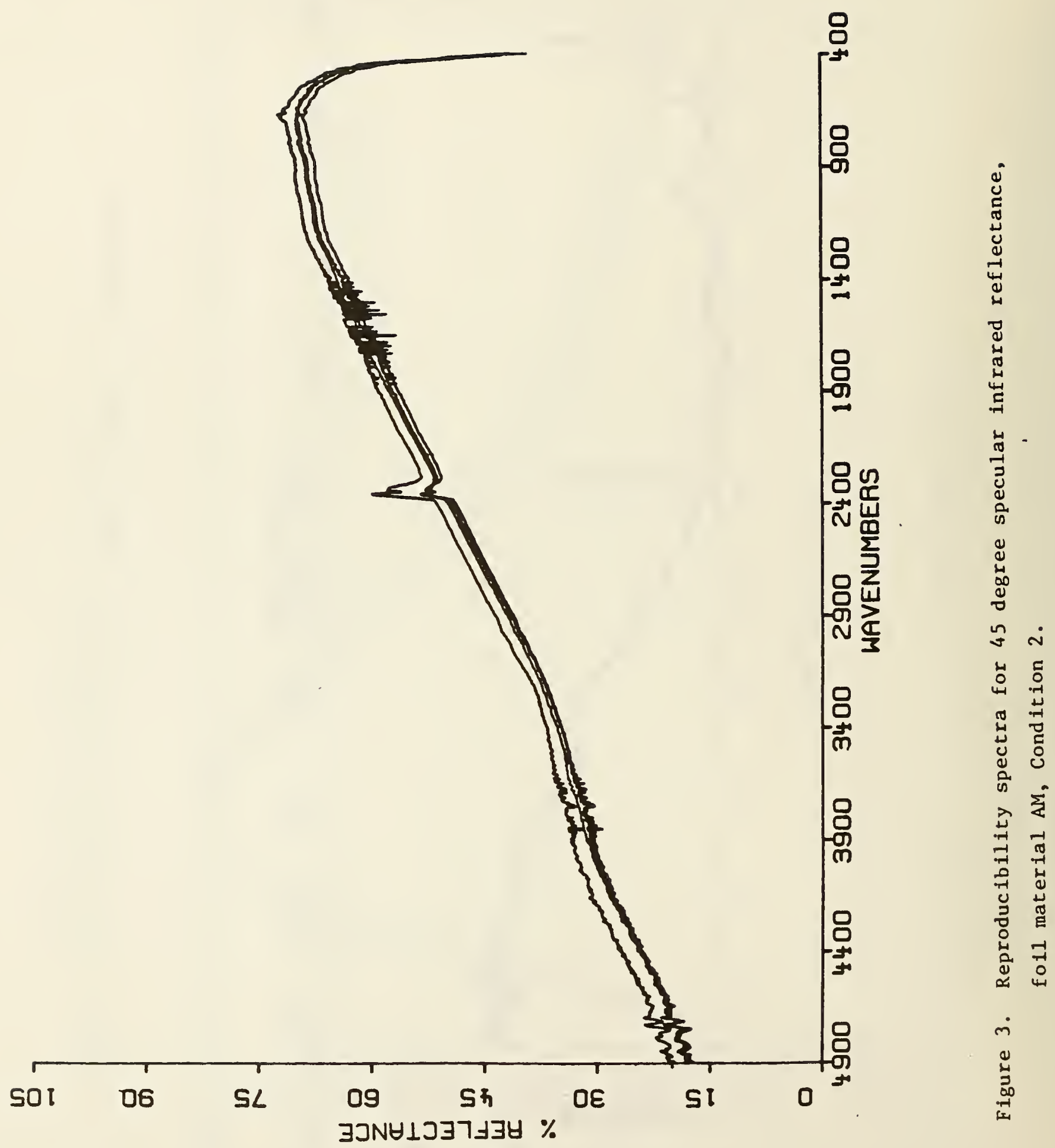




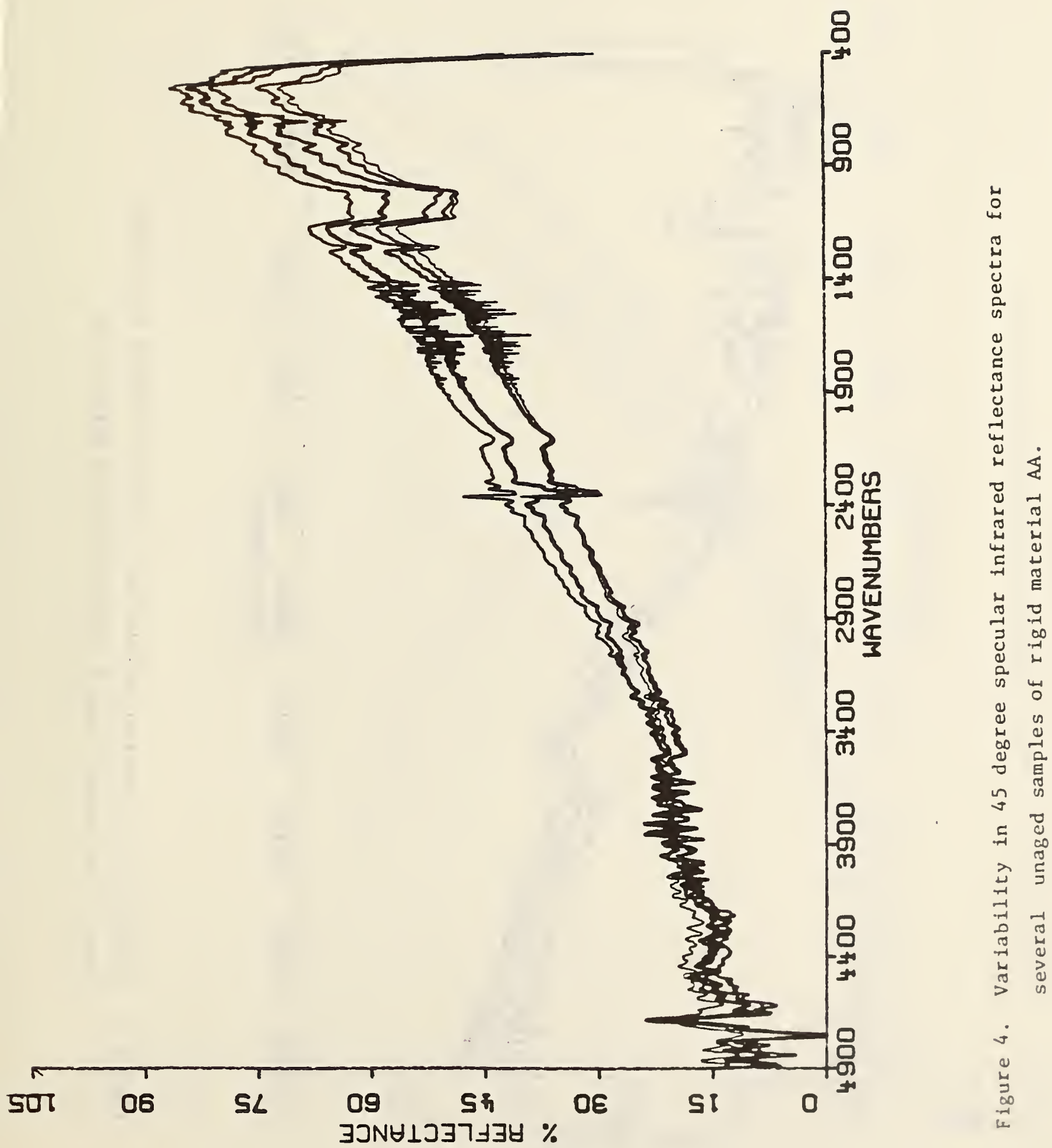




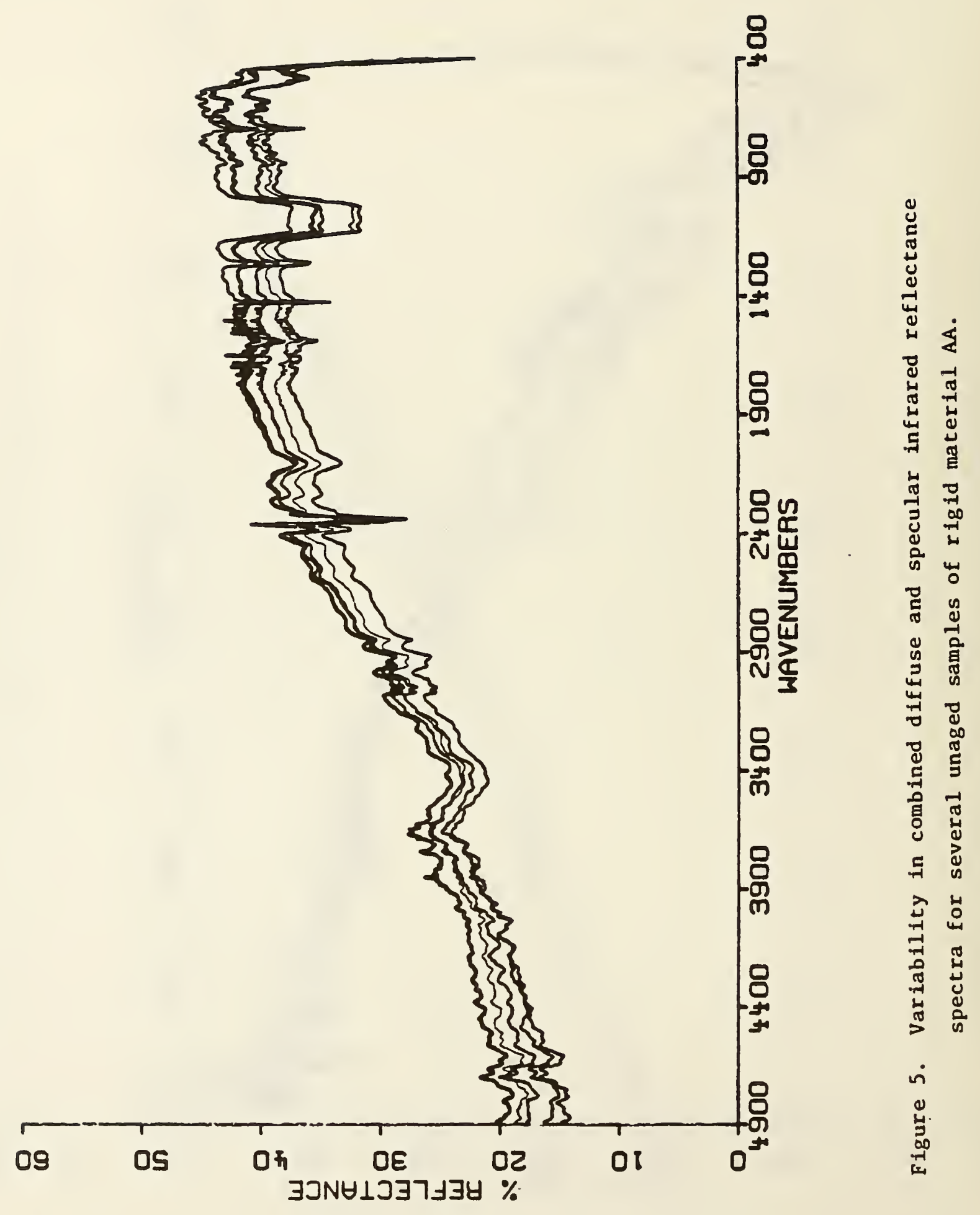




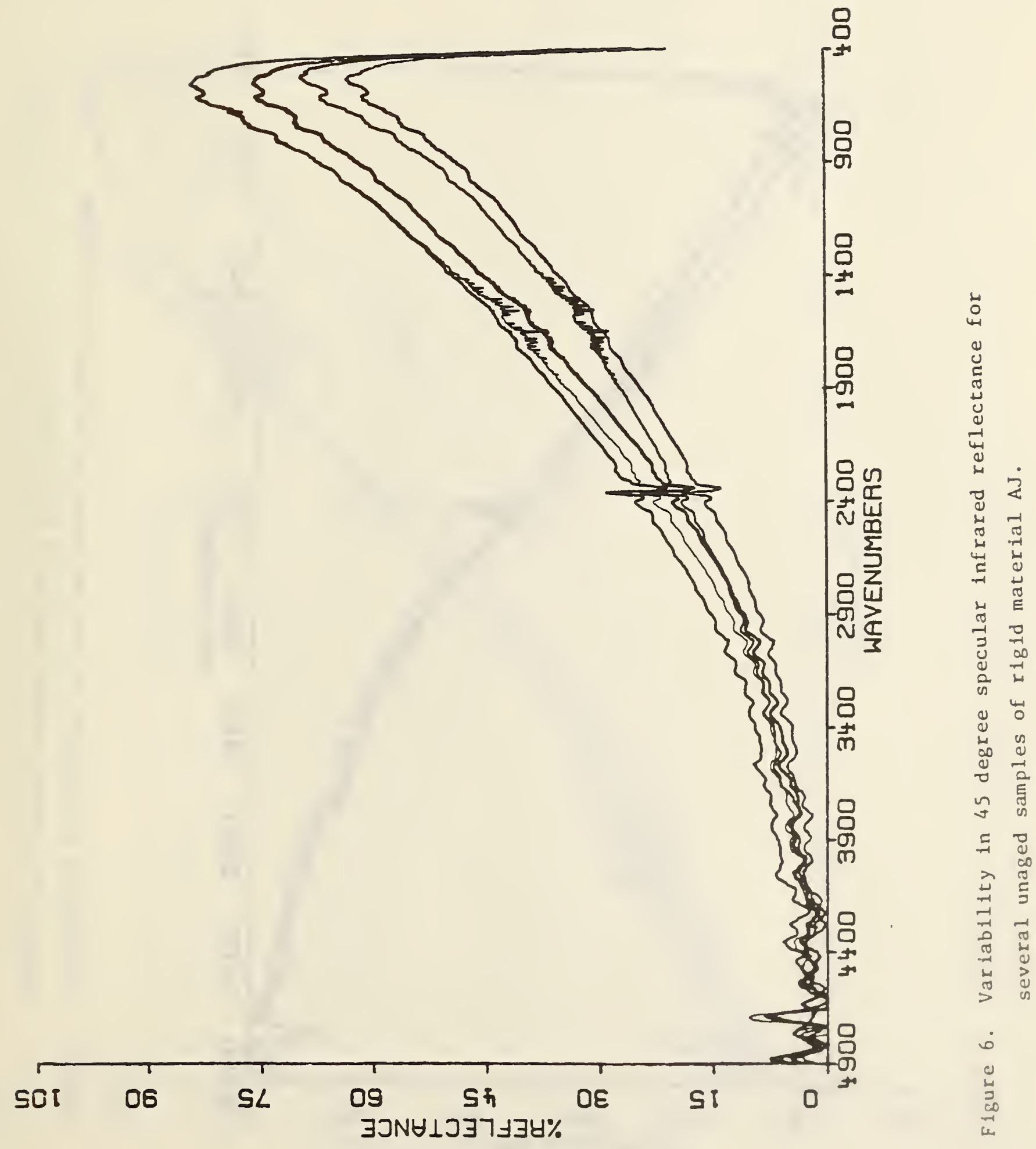




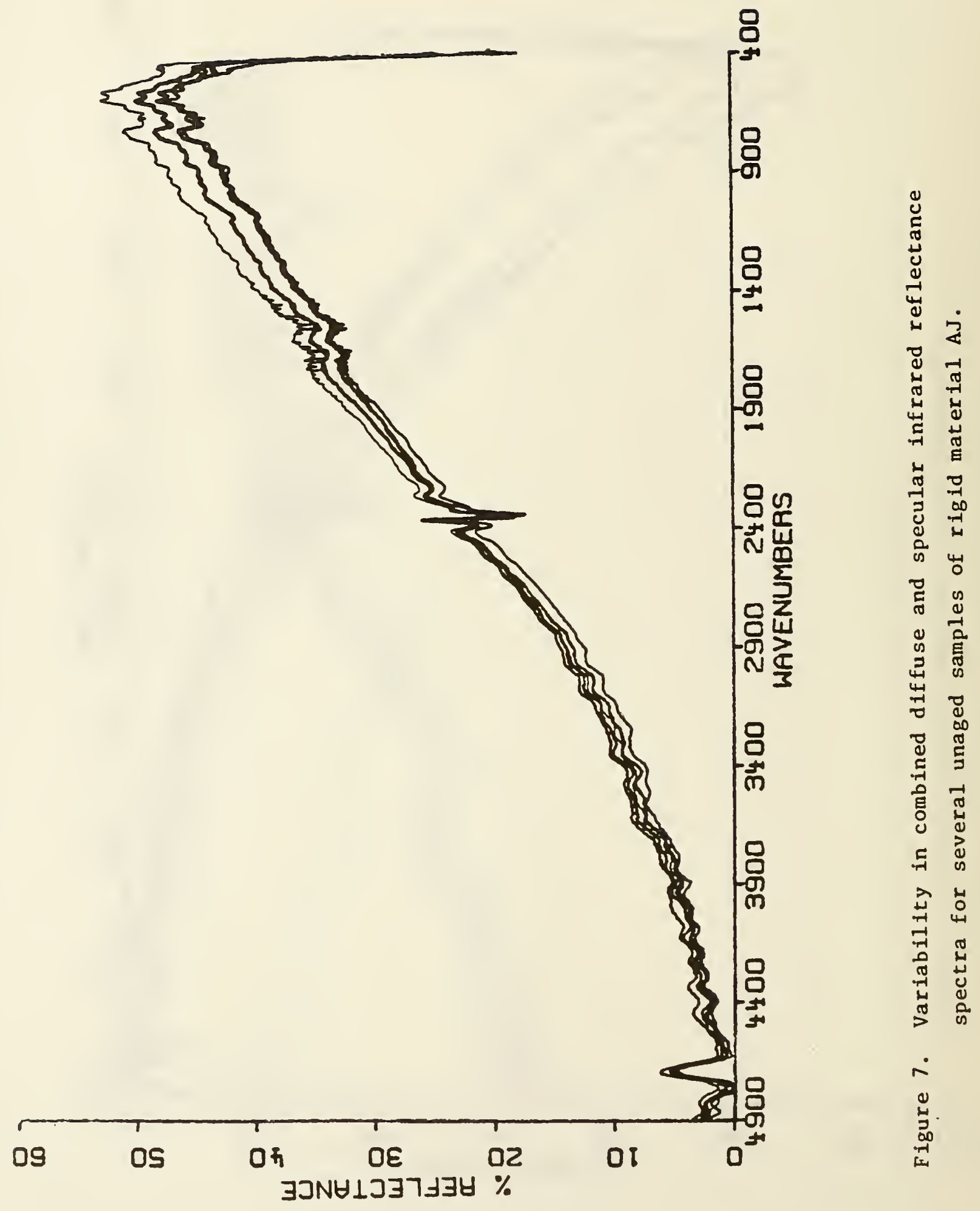




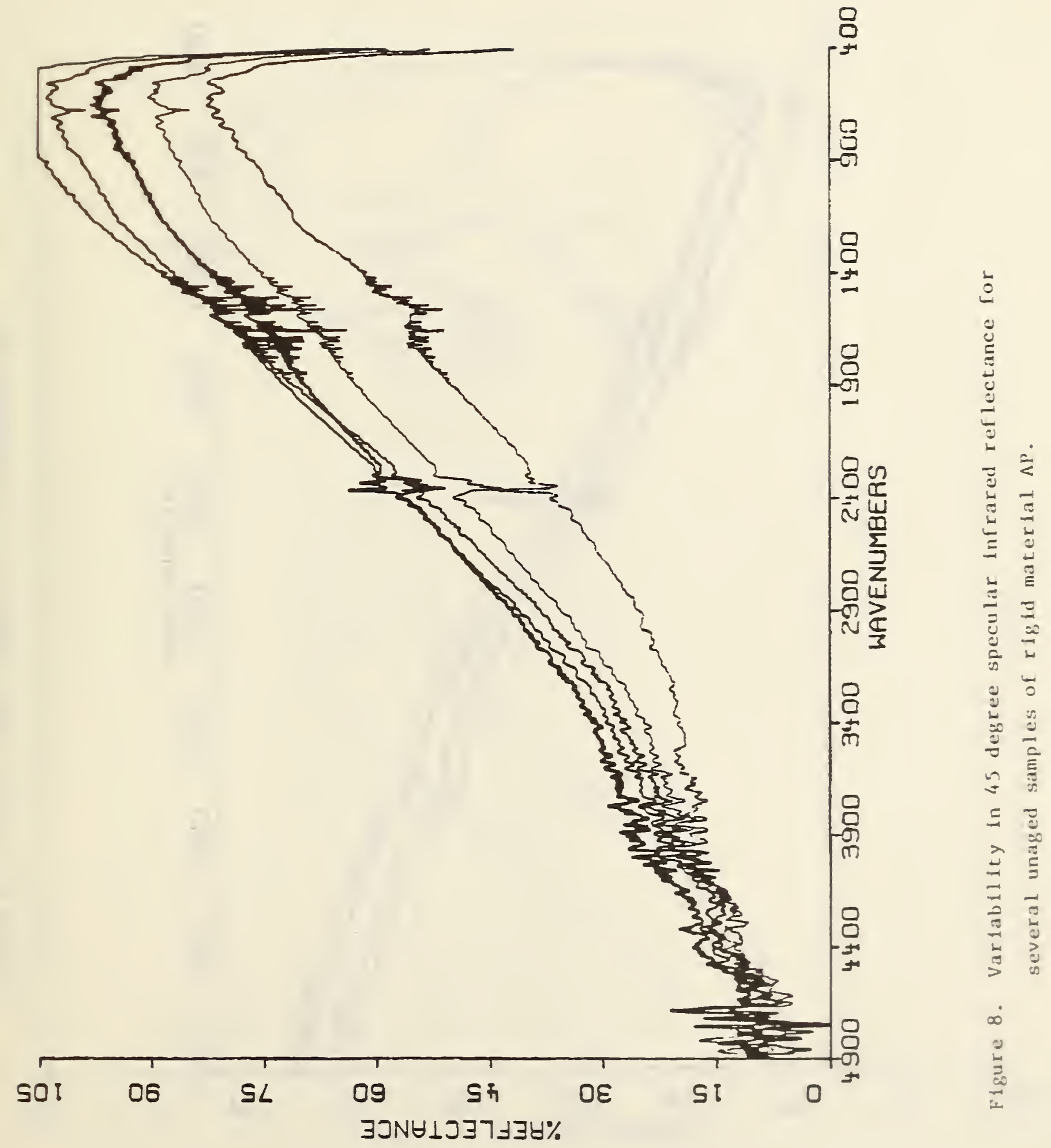




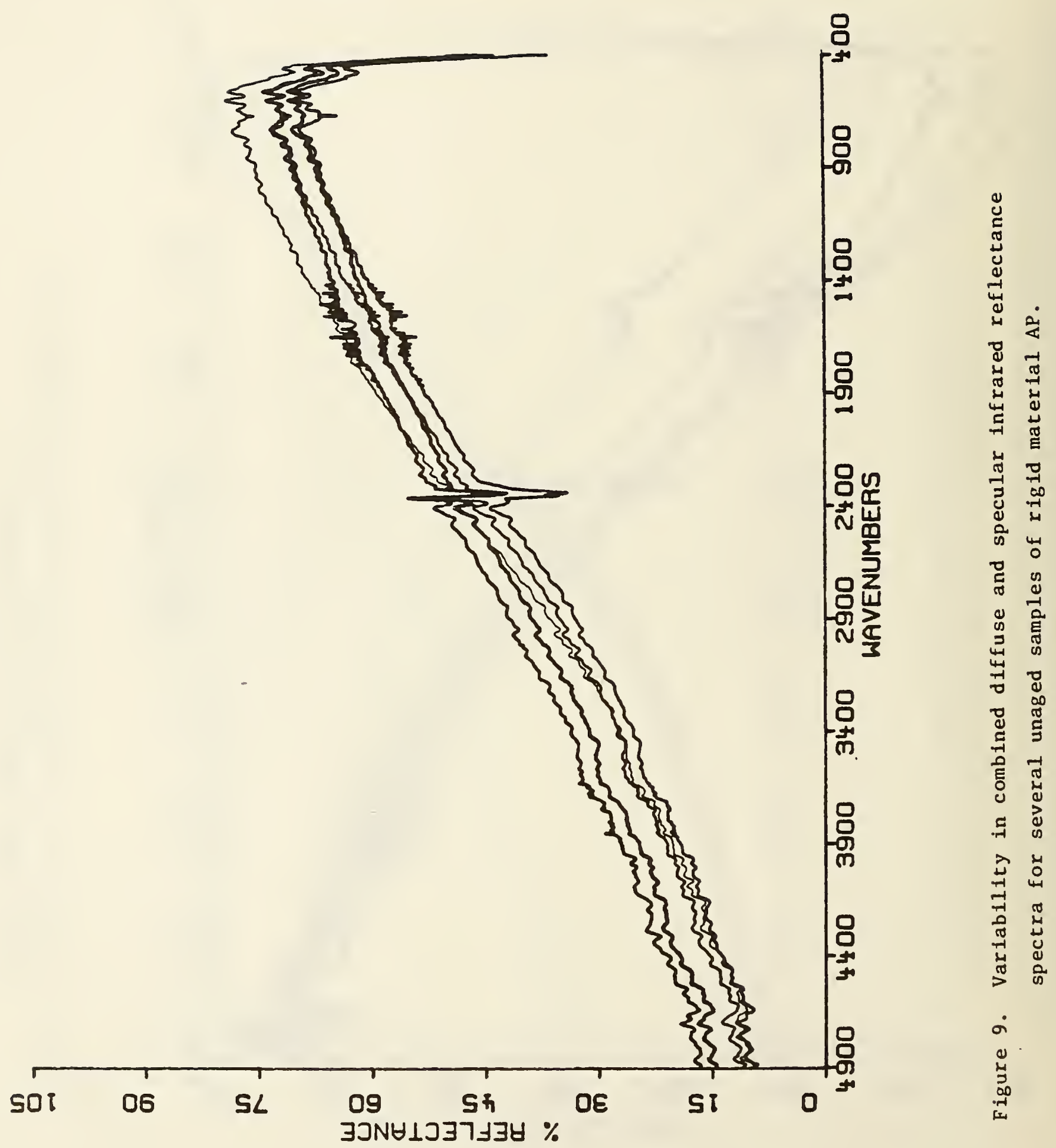




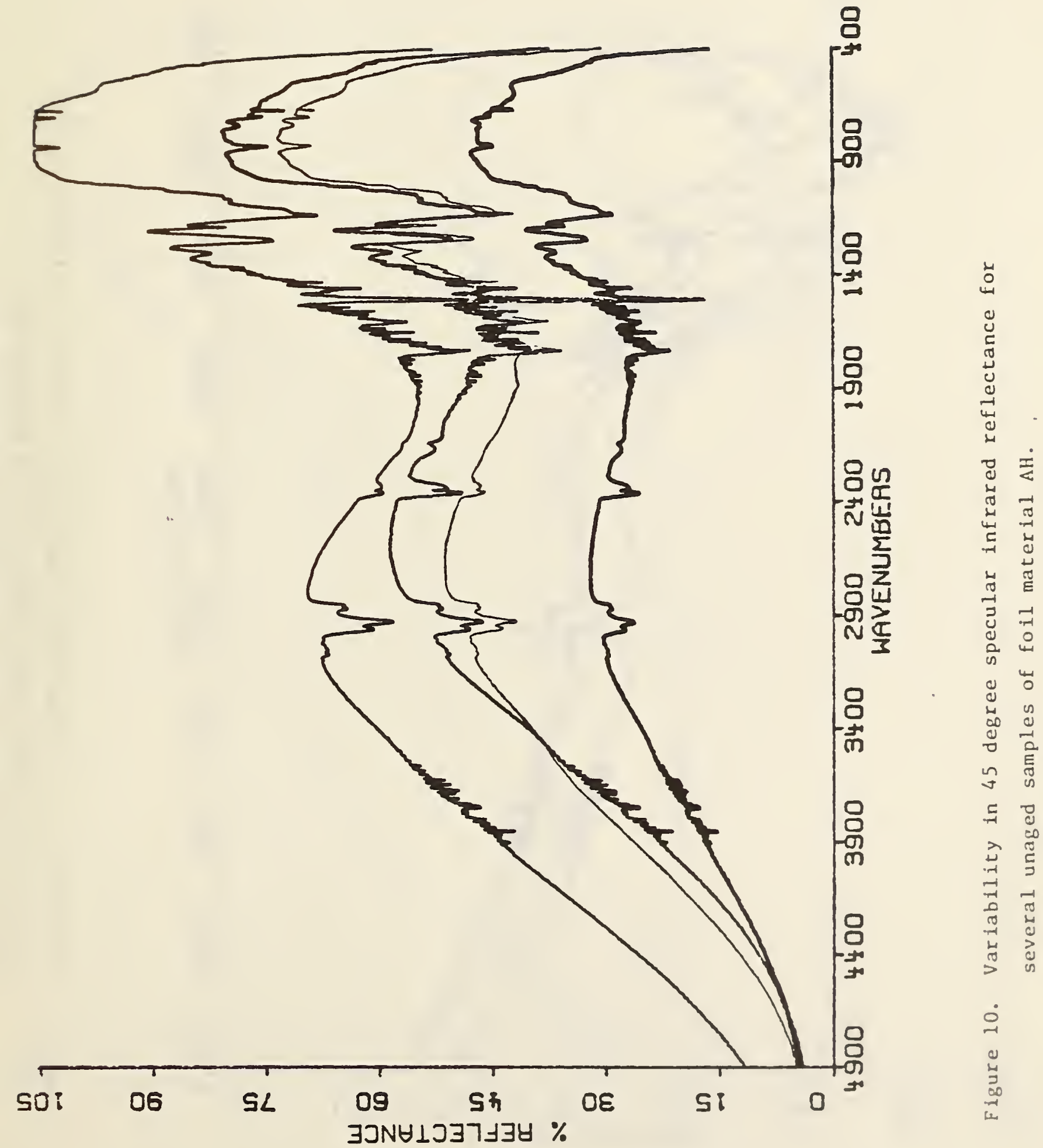




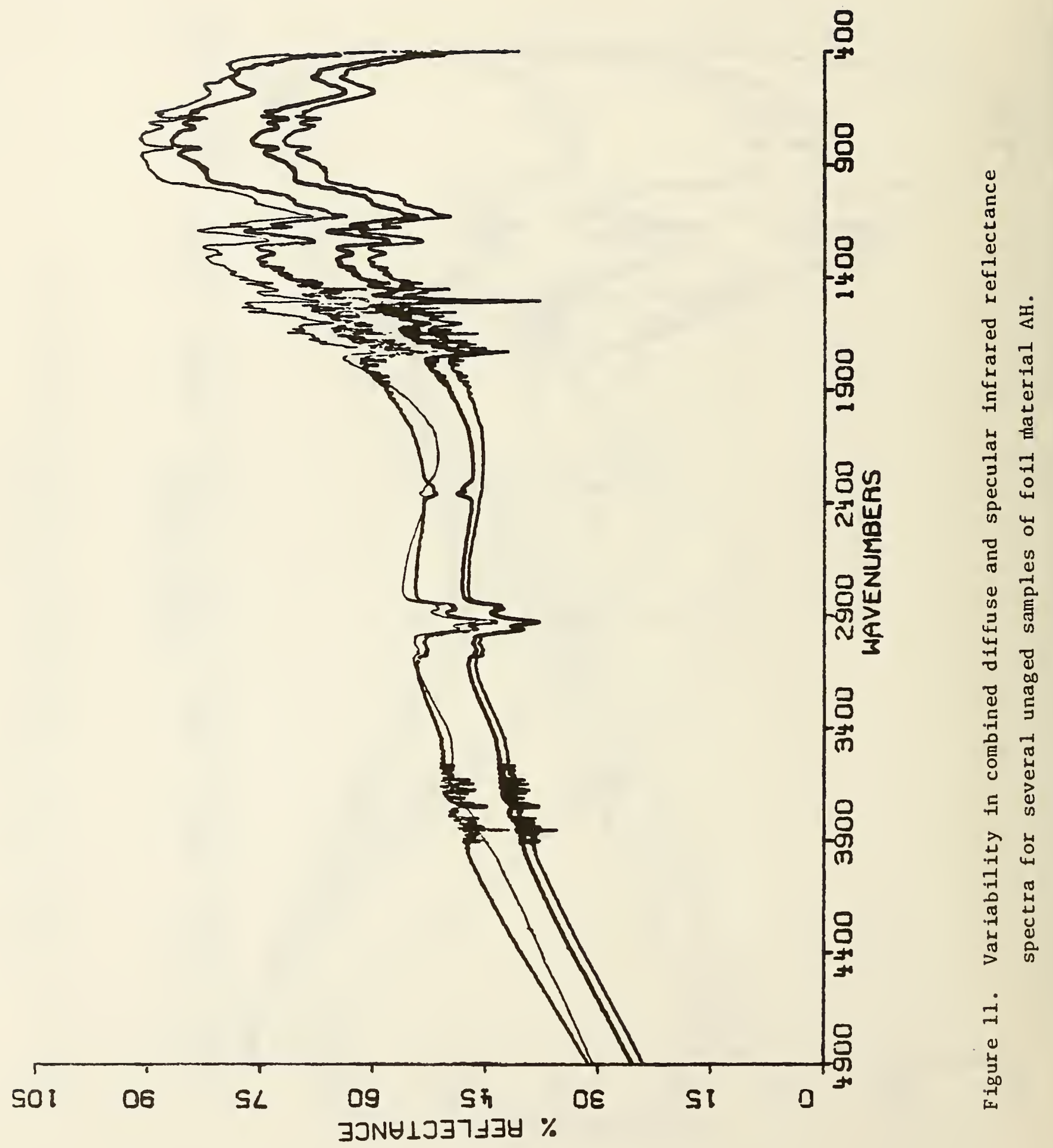




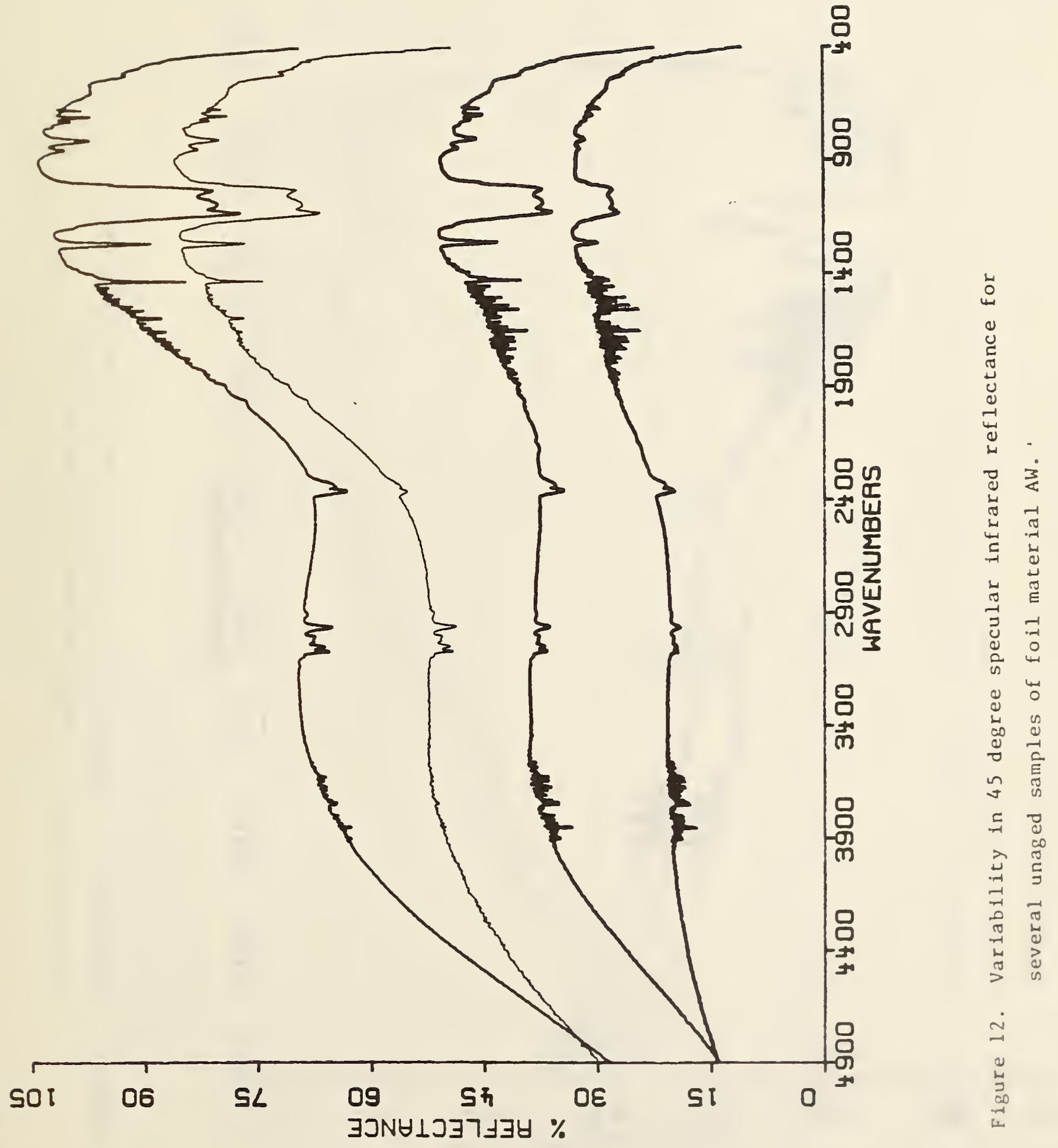




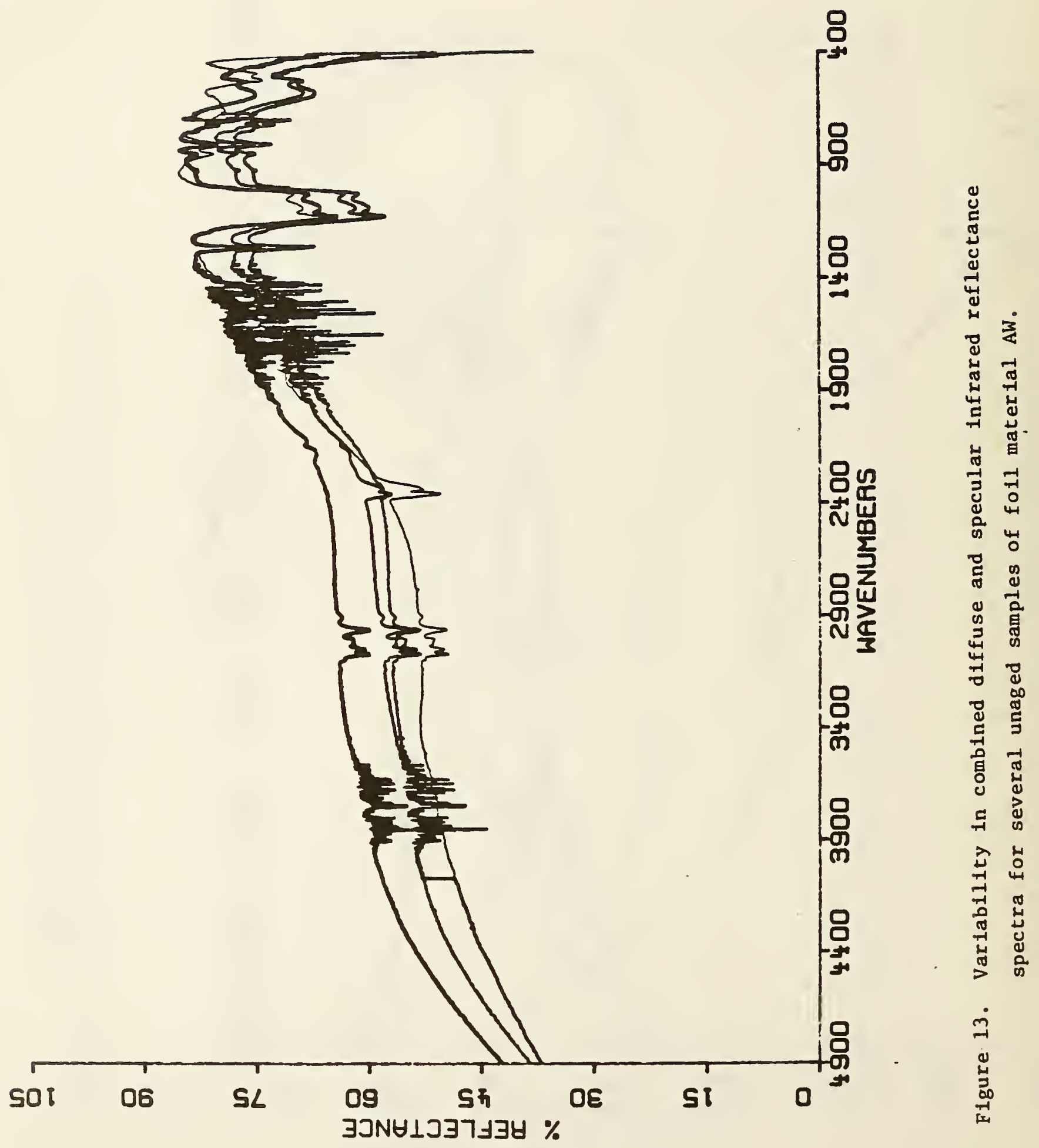




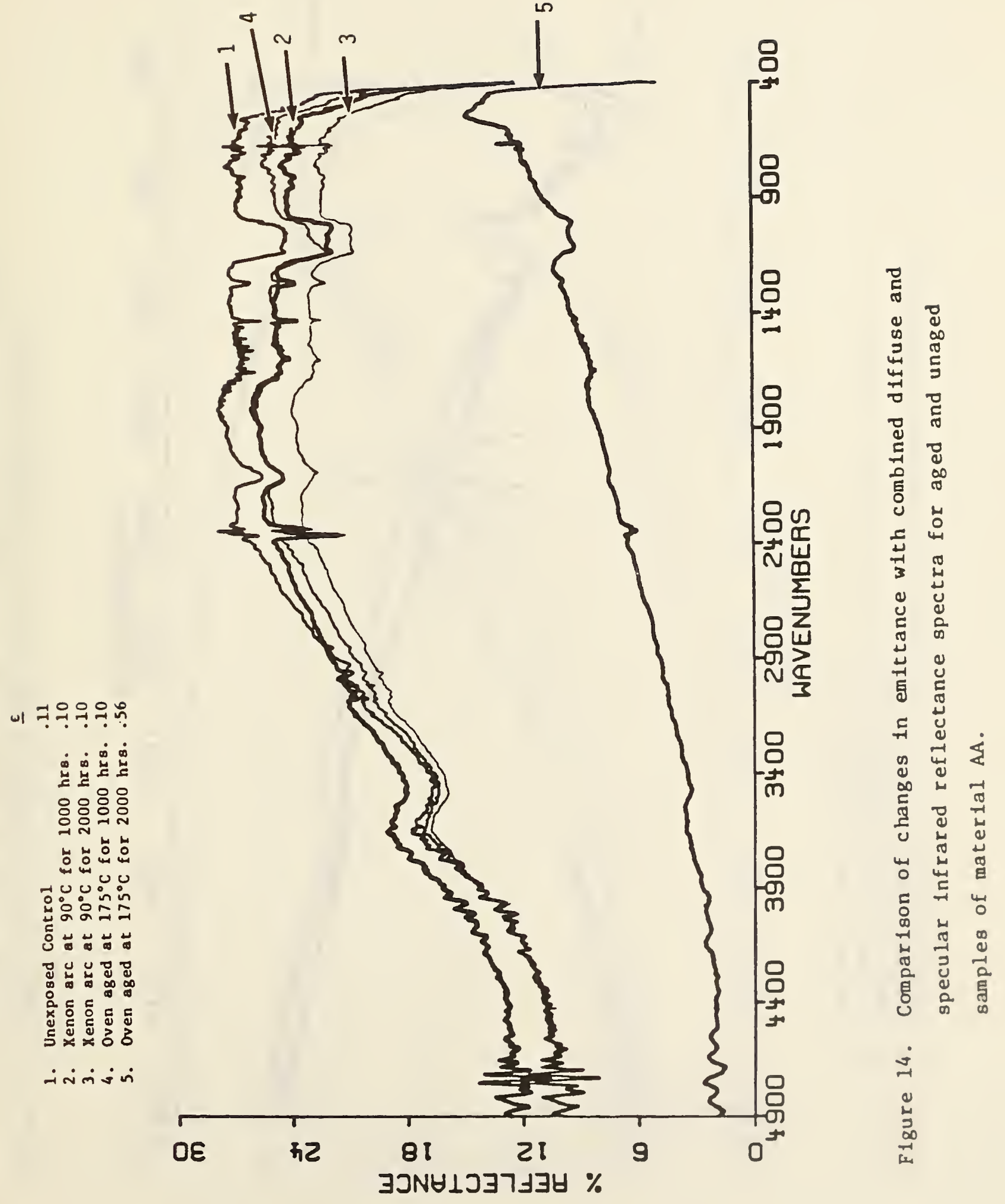


느유우우ํ

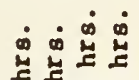

ㅇํㅇ윰ํํำ

点点总

的品。

ํํํㅇํㅇำ

邻狊㟔㟔岸

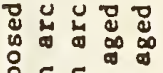

등

突造放

-ivisin

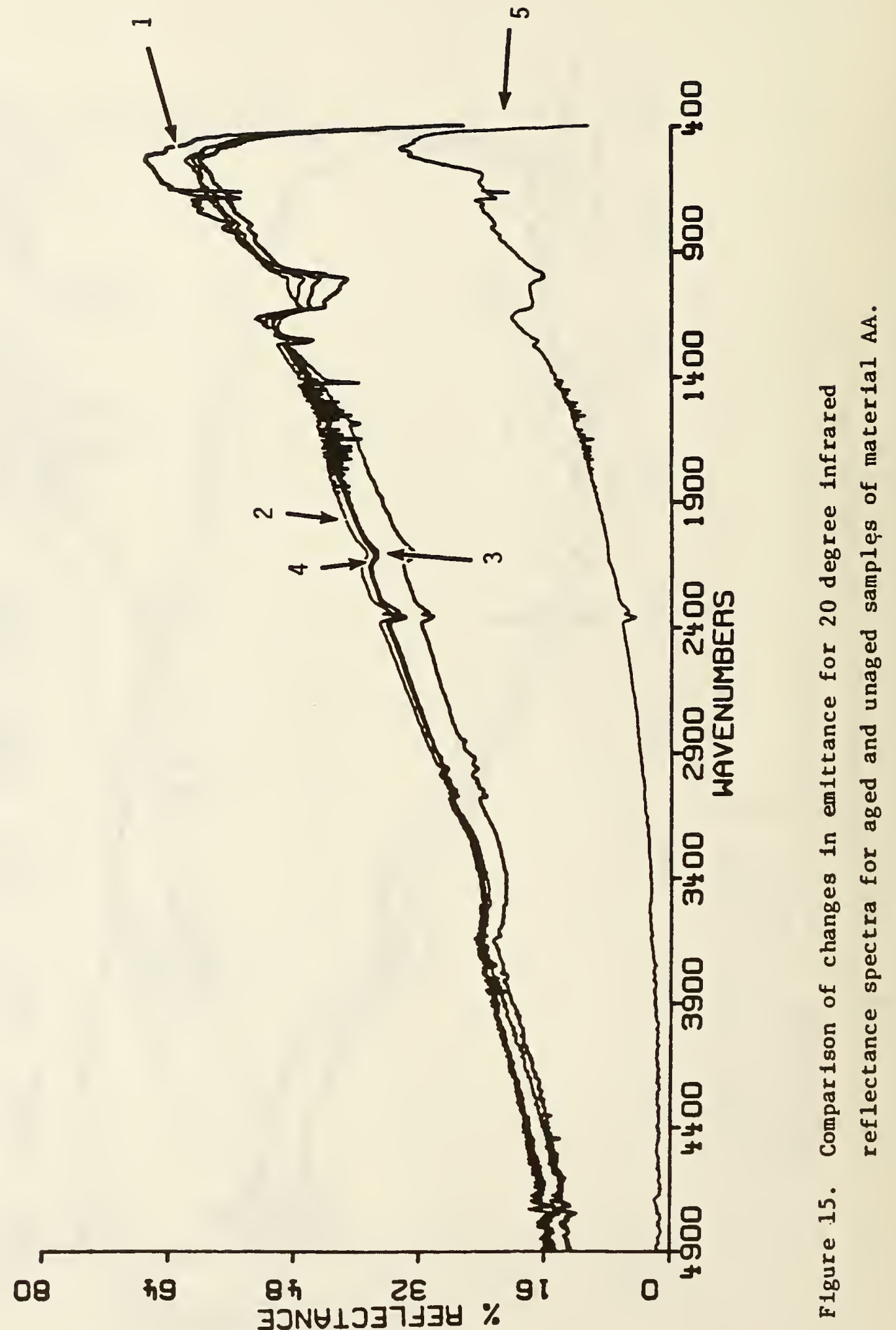


山 그웅ㅇํํ우ํ

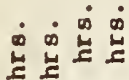

영영융

牙哖

憵总递

T0u․․

ํํํ읓

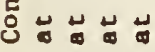

品品品买

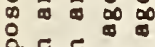

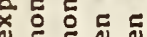

可产方

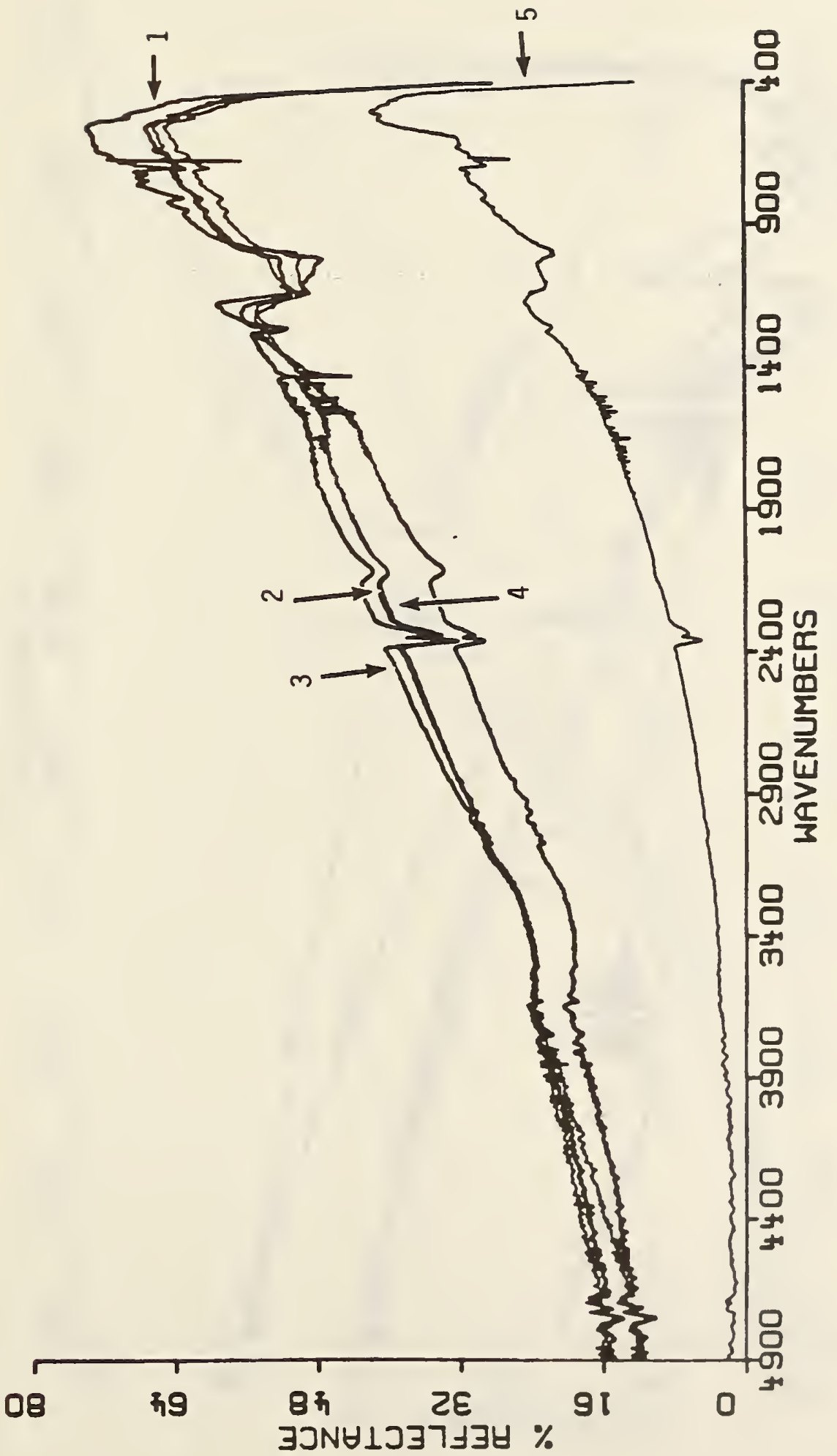

ב

मंतिजि 


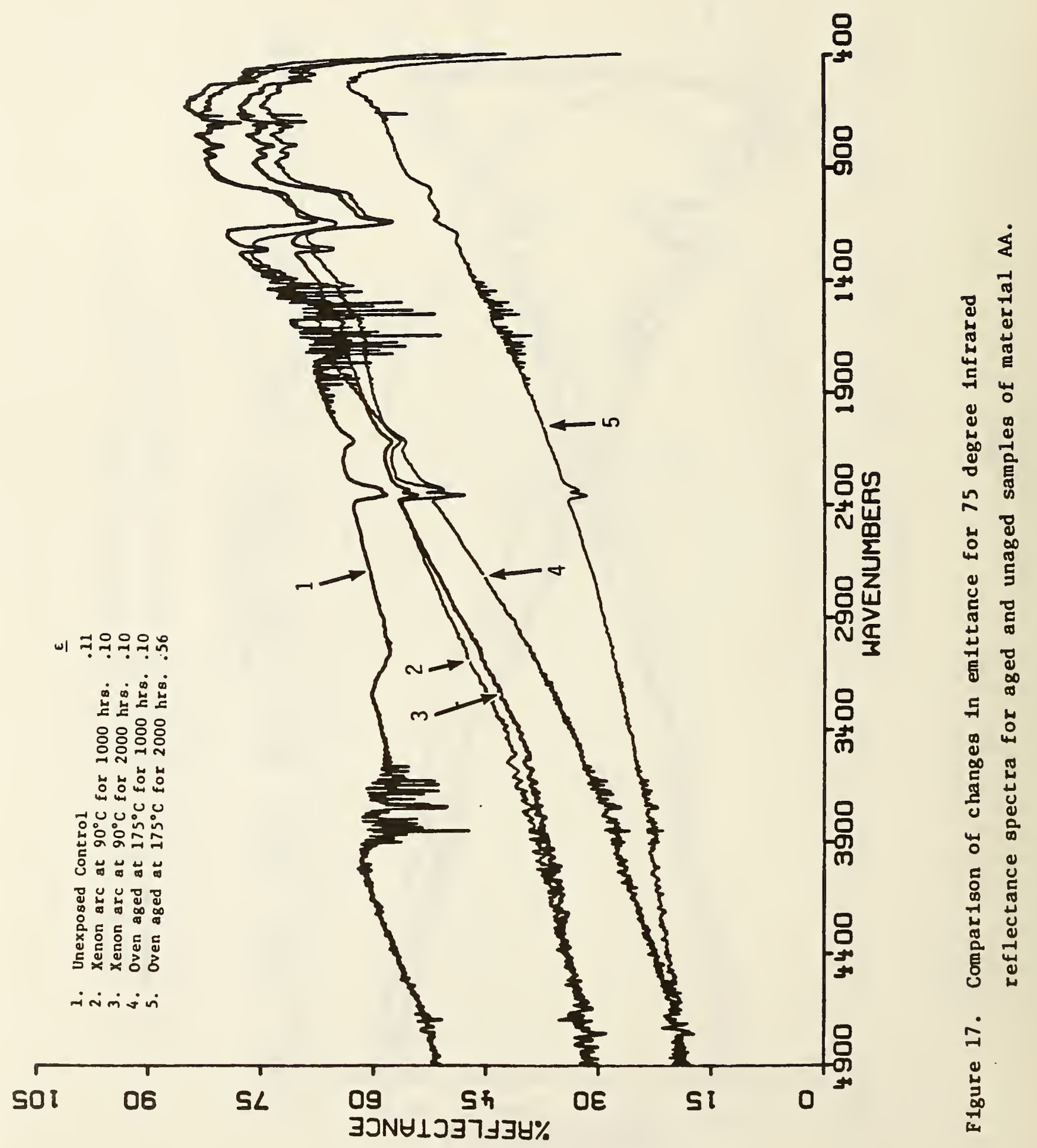


บิ

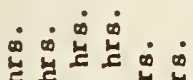
도을 웅융융ㅇㅇ융 ㄴ.

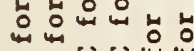

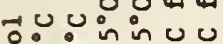

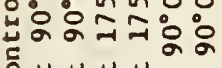

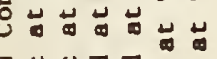

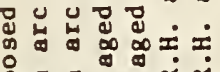
政

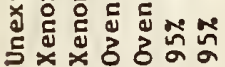
मinision

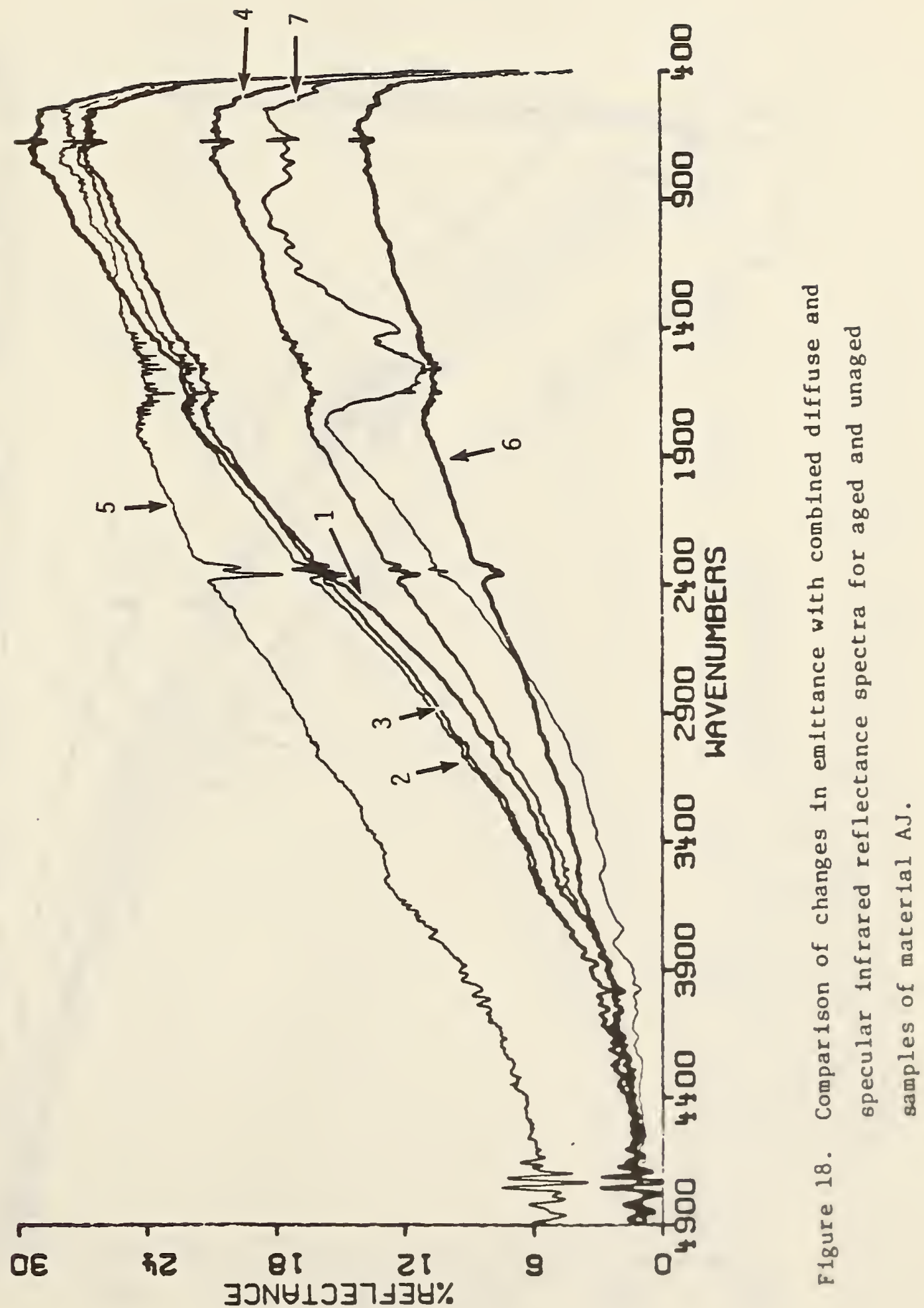




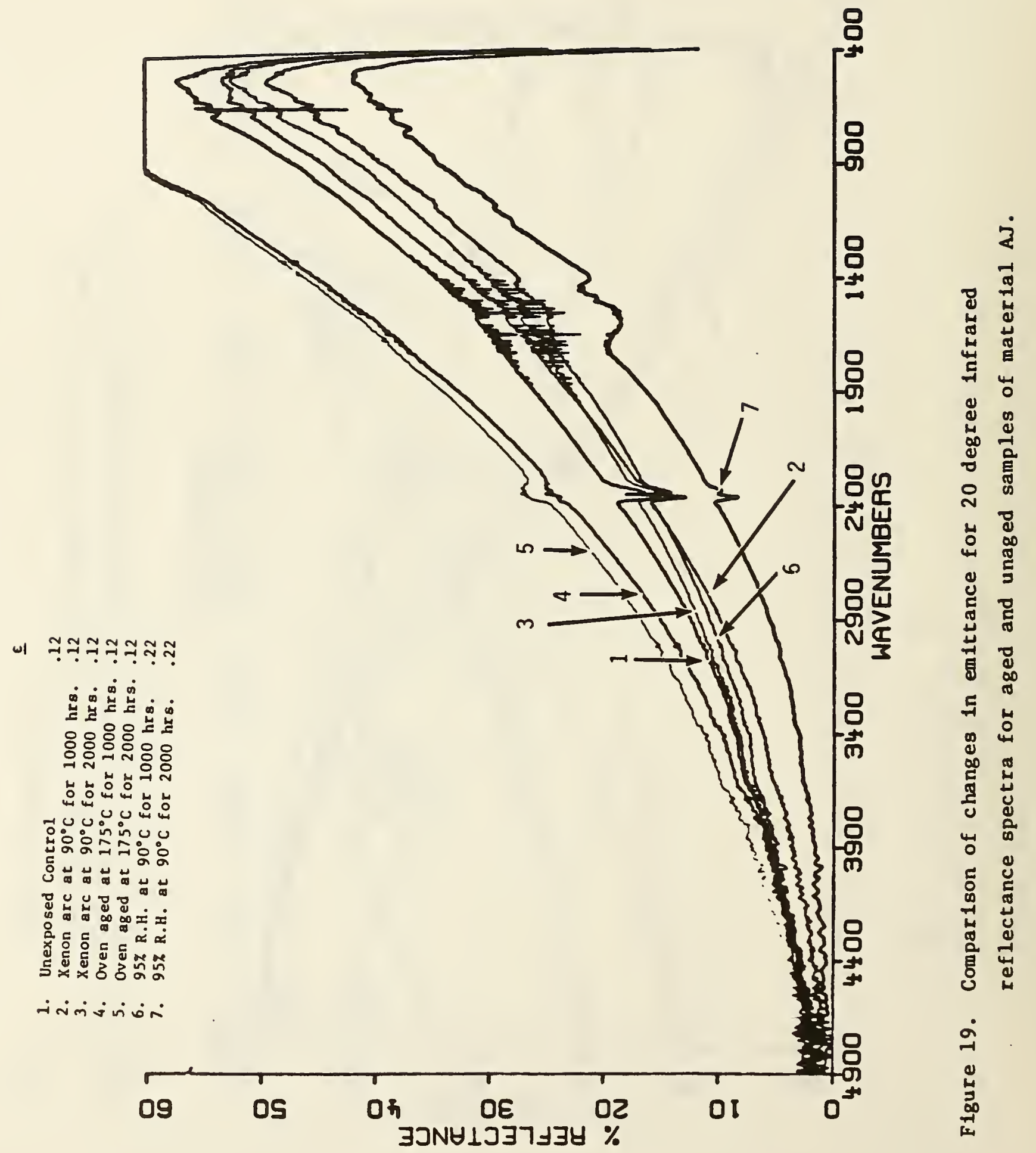




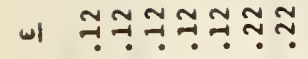

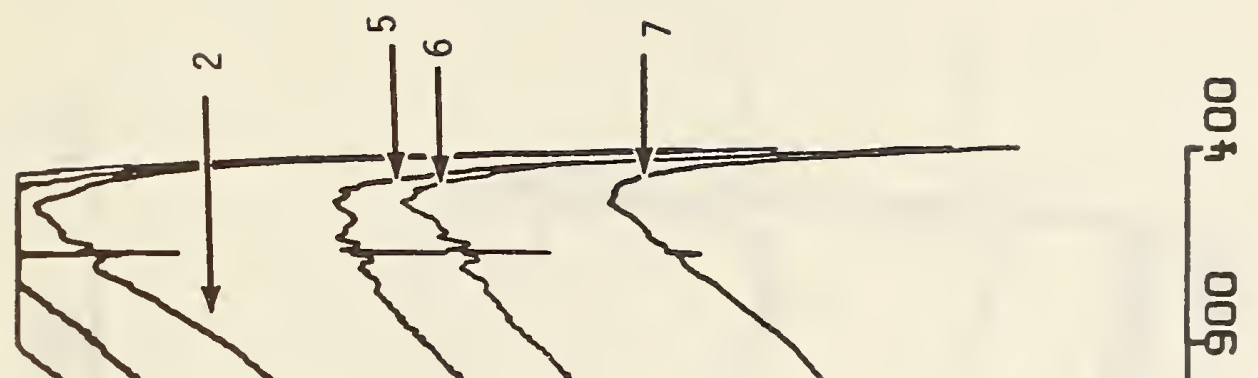

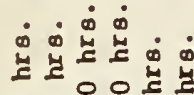

웅유웡ㅇㅇㅇㅇㅇㅇ

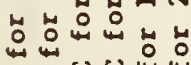

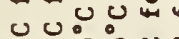

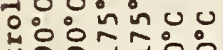

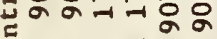

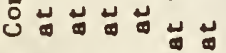

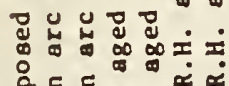

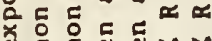

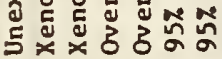

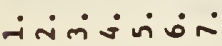

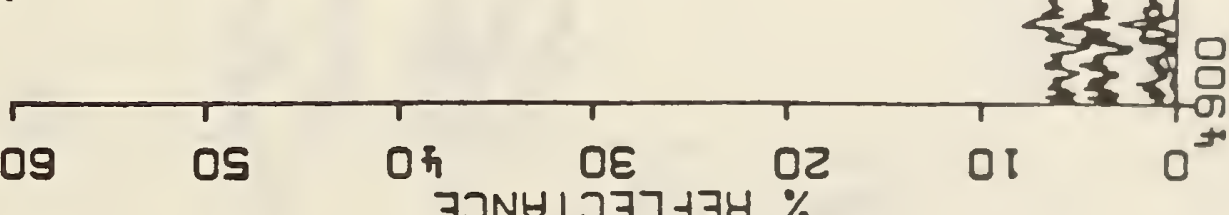

눌 


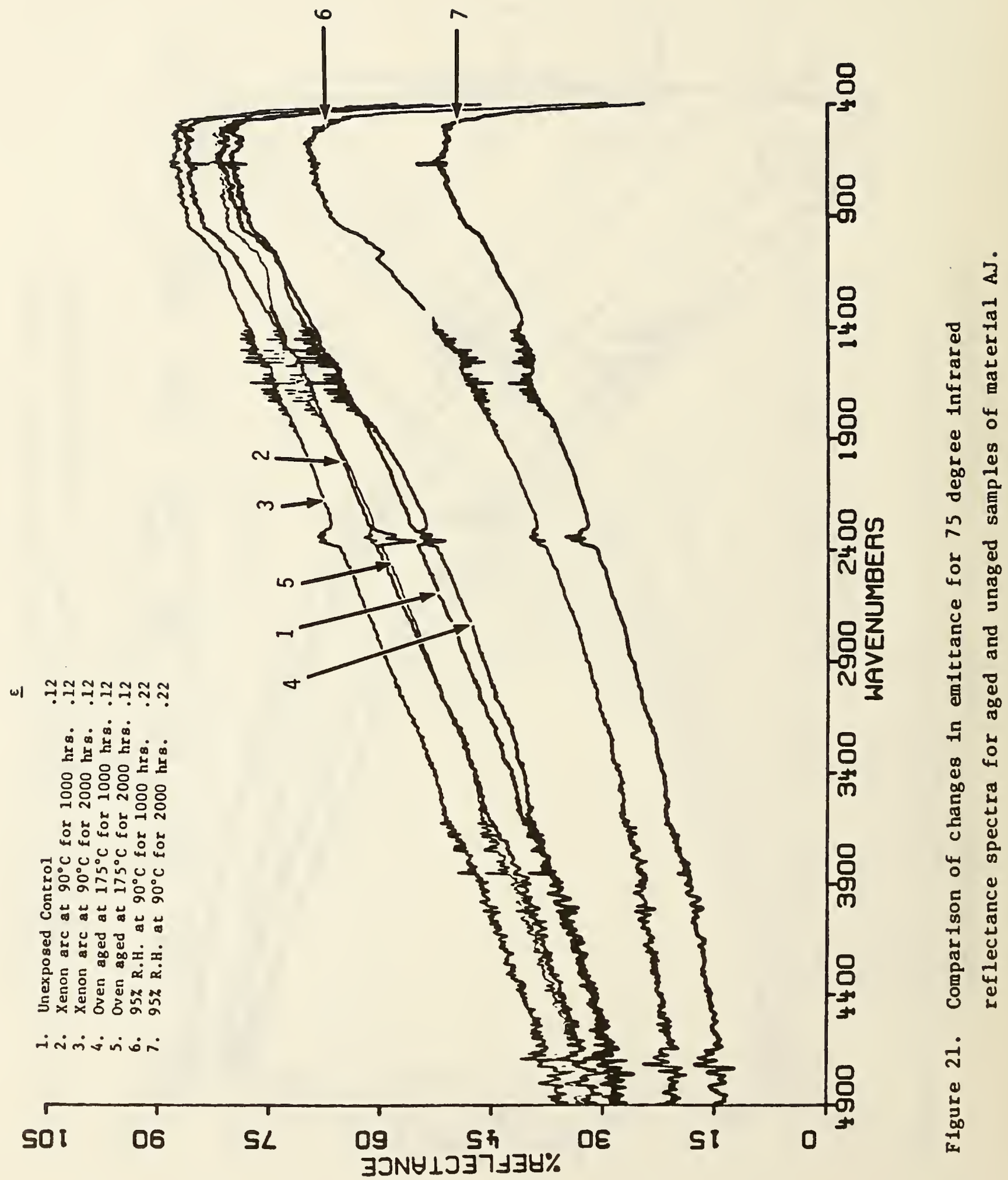


w

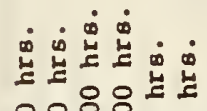
잉융융ㅇㅇㅇ 궁

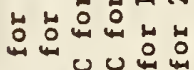
uํㅇํำ ํํำลัํํㅇ

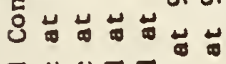

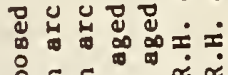
造

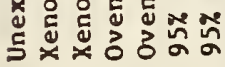

-

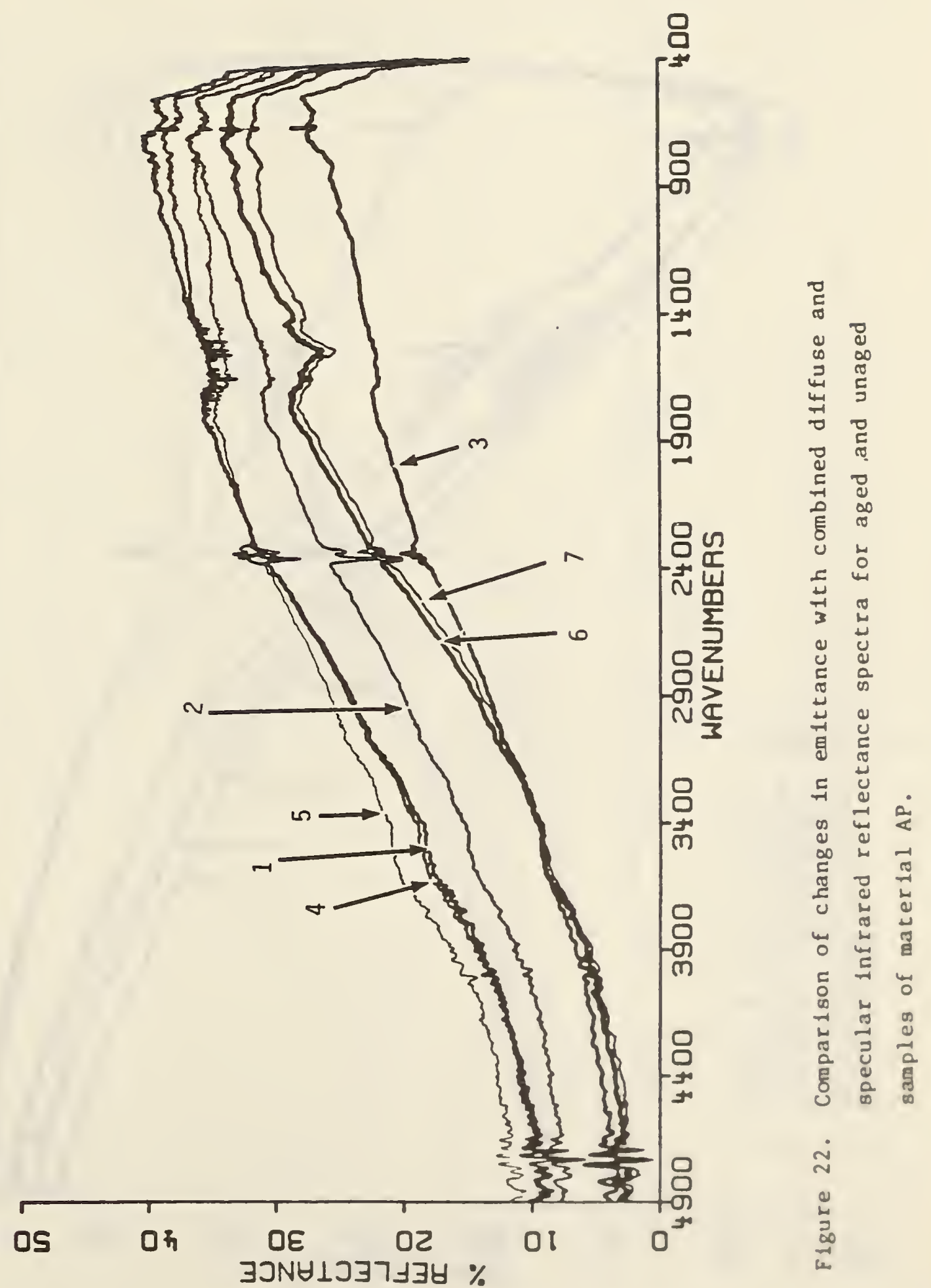


w

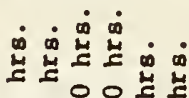

응ㅇㅇ은

잉유융ㅇㅇㅇ

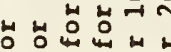

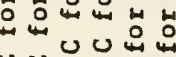

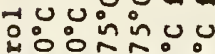

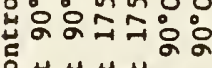

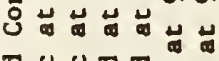

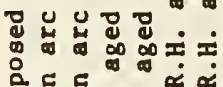

둥

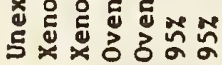

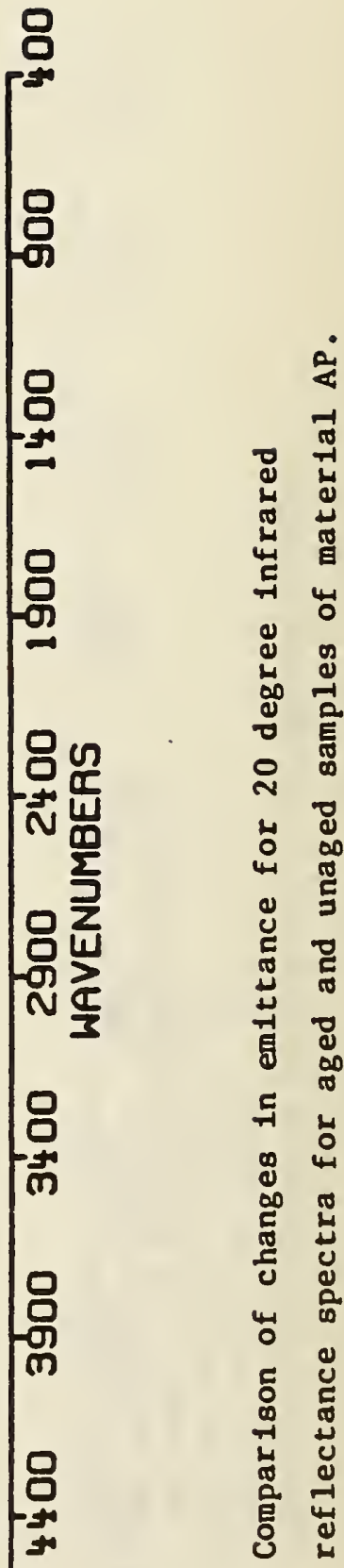

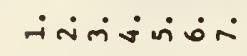
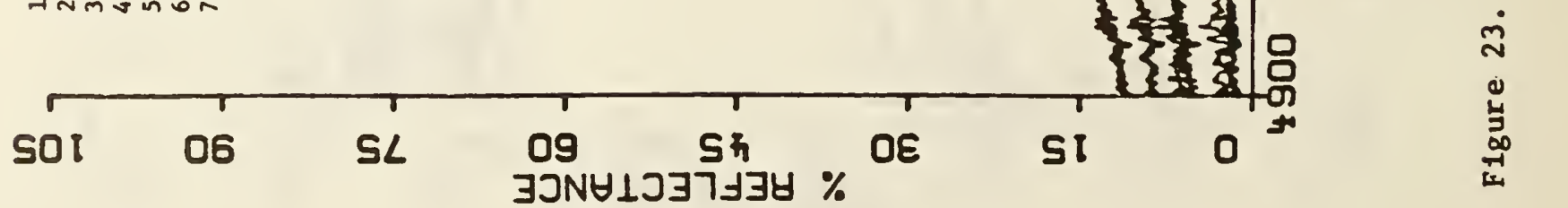


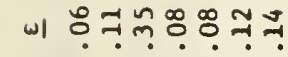

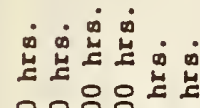

염윰원응

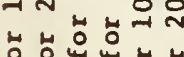

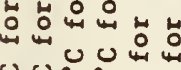

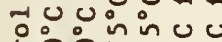

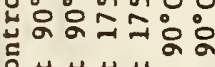

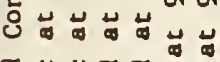

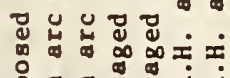

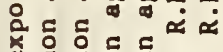

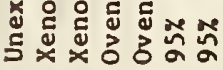

निiminion

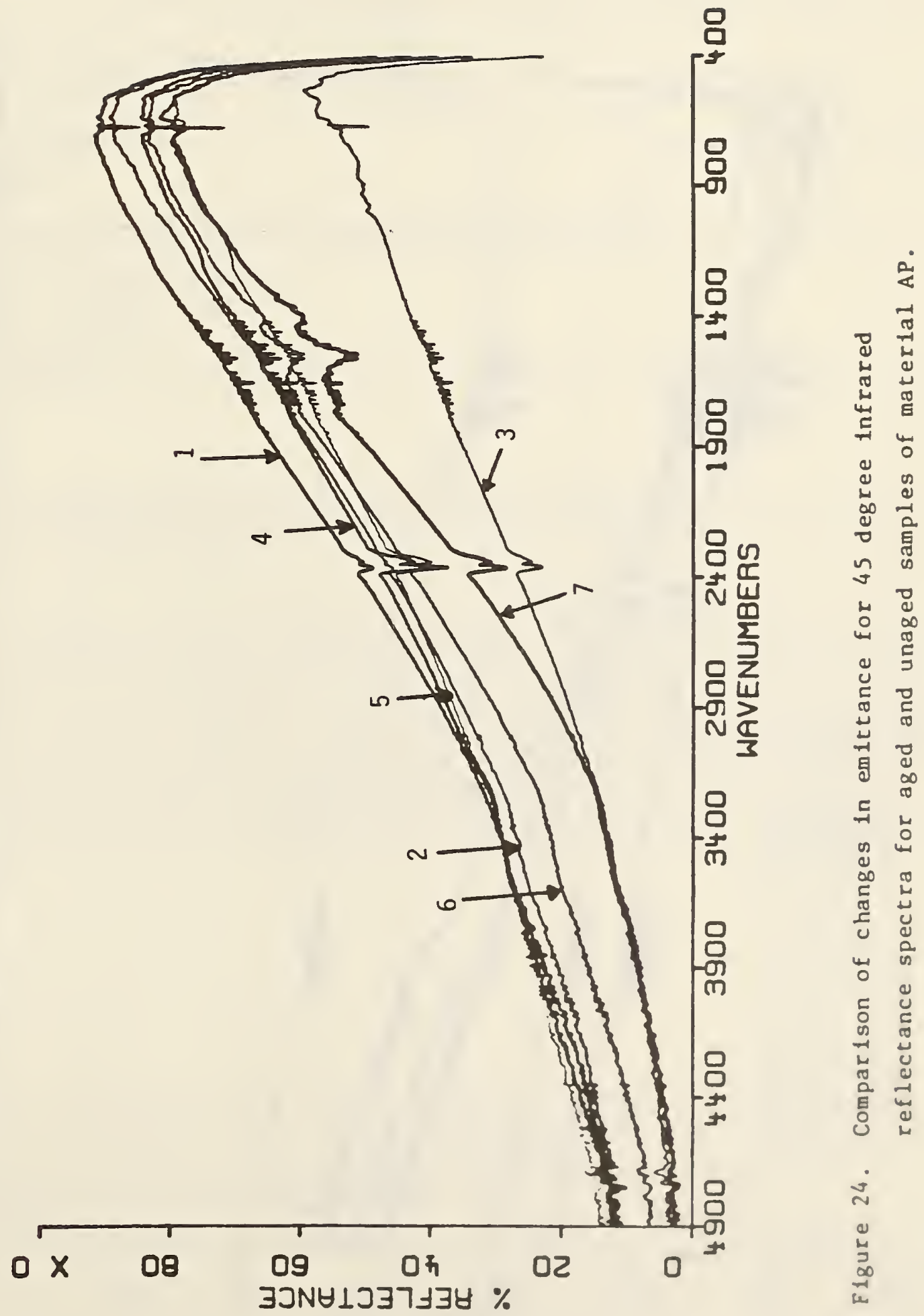




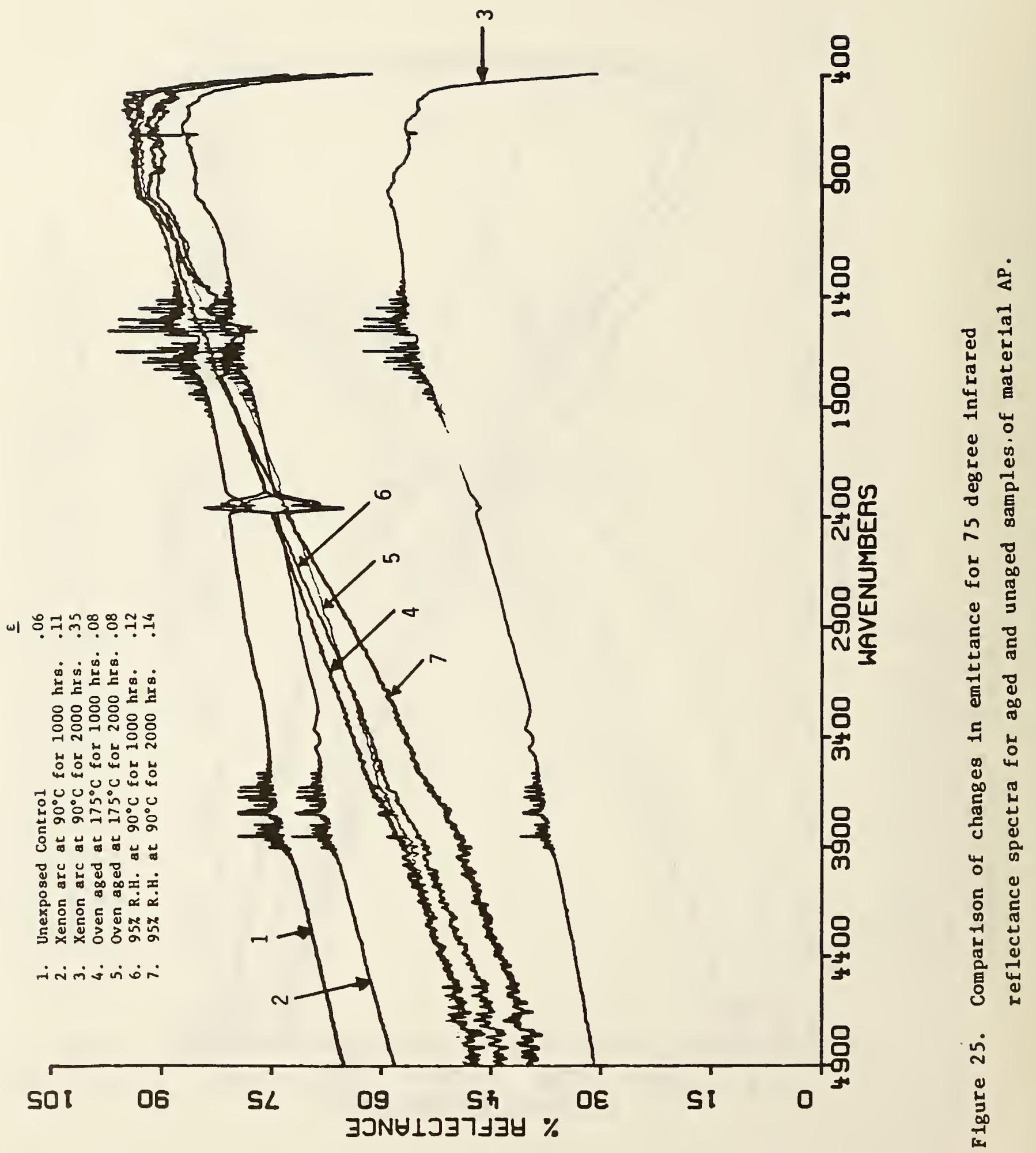


NBS.114A IREV. $2-8 C$ )

U.S. DEPT. OF COMM.

BIBLIOGRAPHIC DATA

SHEET (See instructions)

1. PUBLICATION OR

REPORT NO.

NBSIR 84-2916

2. Performing Organ. Report Nof 3. Publication Date

September 1984

4. TITLE AND SUBTITLE

EVALUATION OF INFRARED REFLECTANCE AS A TECHNIQUE FOR MEASURING ABSORBER

MATERIALS DEGRADATION

5. $A \cup T H O R(S)$

David Waksman; Willard E. Roberts

6. PERFORMING ORGANIZATION (If joint or other than NBS, see instructions)

NATIONAL BUREAU OF STANDARDS

DEPARTMENT OF COMMERCE

WASHINGTON, D.C. 20234

9. SPONSORING ORGANIZATION NAME AND COMPLETE ADDRESS (Street, City, Stote, ZIP)

Active Heating and Cooling Division

Office of Solar Heat Technologies

U.S. Department of Energy

Washington, D.C. 20585

10. SUPPLEMENTARY NOTES

Document describes a computer program; SF-185, FIPS Software Summary, is attached.

11. ABSTRACT (A 200-word or less factual summary of most significant informotion. If document includes a significant bibliogrophy or literoture survey. mention it here)

Current ASTM standards concerned with the durability and reliability of absorptive coatings rely on integrated solar absorptance and emittance as the primary methods for assessing changes in absorber optical performance resulting from environmental exposure. This study was undertaken to determine if infrared reflectance measurements are a more sensitive technique for detecting absorber materials degradation. Spectral measurements were made to identify factors that could affect the reproducibility of infrared reflectance measurements and to compare their ability to detect changes with currently used methods for absorber materials. Recommendations are made concerning the use and limitations of infrared reflectance measurements for this purpose.

12. KEY WORDS (Six to twelve entries; alphabetical order; capitalize only proper names; and seporote key words by semicolons) absorptive coatings; emittance; infrared reflectance; materials degradation; optical performance; solar collectors

13. AVAILABILITY

[X] Unlimited

[ For Official Distribution. Do Not Release to NTIS

$\square$ Order From Superintendent of Documents, U.S. Government Printing Office, Washington, D.C. 20402.

X] Order From National Technical Information Service (NTIS), Springfield, VA. 22161

14. NO. OF PRINTED PAGES $\$ 6$

15. Price 


